.

.

\title{
PLANEJAMENTO ORÇAMENTÁRIO INTRAGOVERNAMENTAL E O PODER JUDICIÁRIO
}

O planejamento governamental, como já se pôde claramente notar, é bastante complexo, e as normas que compõem o sistema jurídico de modo a lhe dar coesão e segurança abrangem uma gama de relaçôes a serem reguladas, cujas dificuldades se tornam maiores em Estados organizados na forma federativa e com nítida separação de poderes, como é o caso do Brasil.

Isso se torna mais evidente no planejamento orçamentário da Administração Pública, em que o sistema jurídico de planejamento prevê normas que se instituem no âmbito de cada unidade federativa, com o PPA, a LDO e a lei orçamentária.

Não é simples estabelecer um sistema coeso nas organizações de grandes dimensões, como é o caso da administração pública federal brasileira, e mesmo nas administrações públicas da maior parte dos Estados e de muitos Municípios, compostas de múltiplos órgãos.

À já previsível dificuldade em coordenar entes federados e respectivos órgãos de modo uniforme, para que todos convirjam em um mesmo sentido, soma-se o fato de que cada unidade federativa é composta por poderes independentes, dotados de autonomia para conduzir sua respectiva administração, o que inclui seus orçamentos e também seu planejamento orçamentário. Uma tarefa necessária e indispensável, que exigirá consideráveis esforços institucionais, como bem observa José Celso Cardoso Júnior. ${ }^{1}$

1 "É preciso, portanto, dispender esforços institucionais, embora consideráveis, nas tarefas de articulação e coordenação em vários níveis, simultaneamente: intra e interpolíticas, programas, 
Cada órgão que compõe a administração pública tem seus interesses, peculiaridades e prioridades, o que, evidentemente, exige um esforço de adaptação com os demais no momento de definir os rumos da administração pública, tanto no âmbito do ente da federação em que está inserido quanto no contexto nacional. Essa adaptação, no entanto, é mais fácil de ser alcançada quando os órgãos integram um único sistema, como se pode admitir que ocorra no âmbito de um mesmo Poder.

No entanto, os Poderes têm constitucionalmente assegurada sua independência, por força da cláusula pétrea insculpida no art. $2^{\circ}$ da Constituição, que se desdobra na autonomia financeira, com capacidade de elaborarem seus próprios orçamentos, também prevista na Constituição de forma expressa, como se vê nos casos do Poder Judiciário (art. 99), do Ministério Público (art. 127, $\$ 3^{\circ}$ ) e da Defensoria Pública (art. 134, $\$ 2^{\circ}$ e $3^{\circ}$ ).

Construir um planejamento orçamentário da administração pública, materializado em leis que produzem seus efeitos na respectiva unidade federada, como é o caso do PPA, da LDO e da LOA, e sendo a unidade federada integrada por Poderes e órgãos constitucionalmente independentes, como os que foram citados, torna necessário organizar um complexo sistema de planejamento orçamentário intragovernamental, com normas capazes de respeitar a independência desses órgãos e poderes, e, ao mesmo tempo, harmonizá-los e coordená-los de forma a assegurar uma unidade de propósitos em função das estratégias e diretrizes do ente federado que integram.

Acresça-se a isso que, na organização do Estado brasileiro, há órgãos e poderes de caráter nacional, que, em sua organização, compõem-se de estruturas formadas no âmbito dos entes subnacionais. Há, por conseguinte, estratégias e diretrizes nacionais a serem seguidas, o que deve ser observado pelas estruturas existentes nas esferas subnacionais. Um exemplo que ilustra bem essa situação é o Poder Judiciário, organizado, em termos federativos, por órgãos com abrangência nacional, como as Cortes Superiores e o Conselho Nacional de Justiça, e tribunais cuja estrutura se insere no âmbito de entes subnacionais, caso dos Tribunais de Justiça nos Estados.

Nesse cenário, o planejamento orçamentário, como já se fez referência, exigirá uma coordenação entre entes federados e poderes independentes capazes de construir um sistema coeso de normas nacionais, federais e estaduais de modo que o sistema de planejamento orçamentário federal - que abrange vários órgãos do Poder Judiciário -, o sistema de planejamento orçamentário dos Estados - nos quais estão

ministérios e órgãos; intra e interinstâncias federativas; intra e interpoderes da República etc. A lista é longa e complexa, mas é dessa reforma profunda (de estruturas, processos e entregas) do setor público estatal que se necessita" (CARDOSO JR., José Celso. Princípios e propostas para o PPA 2016-2019, p. 19). 
outros órgãos do Poder Judiciário -, e o recente sistema de planejamento do próprio Poder Judiciário formem um todo lógico e coerente, sem contradições internas, e capaz de direcionar esse setor da administração pública em função de estratégias, diretrizes e objetivos comuns. Deve-se ainda compatibilizar o sistema de planejamento do Poder Judiciário, que é estabelecido em âmbito nacional não por instrumentos com metodologia de natureza orçamentária, mas de caráter mais amplo, abrangendo aspectos de gestão, o que deve ser observado pelas normas orçamentárias.

O caso do Poder Judiciário, pelas recentes normas de planejamento adotadas pelo Conselho Nacional de Justiça para implantação em todo o Poder Judiciário, em especial as Resoluções ns. 70, de 2009, e 198, de 2014, merece uma análise mais detalhada, a ser feita no item seguinte.

A análise das questões envolvendo o planejamento orçamentário intragovernamental será feita com base no Poder Judiciário, em que será possível observar os problemas mais relevantes e frequentes, dada sua autonomia, expressa não somente no art. $2^{\circ}$, como também no art. 99, que delineia seus contornos e a detalha; e também, e principalmente, sua elevada dimensão como órgão da administração pública. Nesse último aspecto, o Poder Legislativo é significativamente menor, não obstante sua elevada importância em termos políticos. E o Poder Executivo é o que exerce as principais funções como gestor na administração pública, não sendo necessário fazer referência específica, uma vez que é basicamente com os outros poderes, especialmente o Poder Judiciário, com o qual surgirão os conflitos e problemas. Acresça-se que o Poder Judiciário é aquele com o qual surgem, em termos quantitativos e qualitativos, os maiores conflitos. O Poder Legislativo, nos problemas que surgem, não difere em essência do Poder Judiciário, e a possibilidade de solução política por ajustes entre o Poder Legislativo e o Poder Executivo é mais frequente, tornando menos intensas e necessárias as decisões jurídicas. É relevante também destacar que o Poder Judiciário é a principal instituição na administração da Justiça, pois suas decisóes administrativas

"afetam e conduzem os demais órgãos, pessoas e instituições essenciais à Justiça. É por iniciativa do Poder Judiciário que se define a instalação de novos fóruns e comarcas, é ele quem conduz os processos, e, mais recentemente, implanta sistemas de processo eletrônico aos quais terão de se adaptar o Ministério Público, a Defensoria, a Advocacia, auxiliares da Justiça e os cidadãos. Daí porque se torna mais relevante o planejamento de seu futuro e suas açôes, tornando-os transparentes e previsíveis, a fim de que todos que dele dependam e com ele se relacionam possam também se planejar". ${ }^{2}$

2 CONTI, José Mauricio. Poder Judiciário: 2014 é o ano do planejamento estratégico. Levando o direito financeiro a sério, p. 145-149. 


\subsection{PLANEJAMENTO E COORDENAÇÃO INTRAGOVERNAMENTAL: O PODER JUDICIÁRIO}

O Poder Judiciário, como um Poder do Estado, ao exercer a função jurisdicional, é responsável pela prestação de um serviço público essencial. Para isso, em face da já gigantesca e ainda crescente demanda, foi preciso assumir dimensões que tornam necessário fazer dele um órgão expressivo da Administração Pública, em todos os sentidos, especialmente no que tange ao uso de recursos financeiros, humanos e materiais, como se pode constatar. ${ }^{3}$

A cúpula do Poder Judiciário está organizada no Brasil tendo como órgãos o Supremo Tribunal Federal, o Superior Tribunal de Justiça e os Tribunais Superiores do Trabalho, Militar e Eleitoral, que integram a administração pública federal, exercendo competências de âmbito nacional, uma vez que julgam recursos oriundos dos tribunais de todo o País, inclusive dos tribunais estaduais. O Poder Judiciário, no âmbito federal, é composto pela "Justiça Comum" e pelas "Justiças Especiais". A "Justiça Comum" tem como órgãos de segunda instância os Tribunais Regionais Federais e, na primeira instância, os Juízes Federais. O Conselho da Justiça Federal (CJF), que funciona junto ao Superior Tribunal de Justiça, é responsável pela supervisão administrativa e orçamentária da Justiça Federal de primeiro e segundo graus, como órgão central do sistema (CF, art. 105, parágrafo único, II), tendo importantes funçôes no âmbito de planejamento e orçamento. Nas "Justiças Especiais", estão os Tribunais e Juízes do Trabalho, os Tribunais e Juízes Eleitorais e os Tribunais e Juízes Militares. ${ }^{4} \mathrm{Na}$ esfera estadual, os Tribunais de Justiça e Juízes de Direito.

A reforma administrativa do Estado, que se intensificou a partir da Emenda Constitucional n. 19, de 1998, e a implementação do Plano Diretor da Reforma do Aparelho do Estado (PDRAE), voltado a transformar a administração pública

O Tribunal de Contas da União fala em "dupla personalidade": "Com a promulgação da Constituição Federal de 1988, o modelo de presidencialismo adotado imprimiu ao Judiciário uma dupla personalidade: a de Poder de Estado e, alter facie, a de instituição prestadora de serviços essenciais à paz social. Na vertente Poder, assumiu a competência para deliberar politicamente, quer questionando, quer paralisando a aplicação de leis e atos administrativos pelos poderes (Executivo e Legislativo), ou mesmo determinando medidas, independentemente da vontade expressa (desses). Noutra vertente, a instituição possui atribuições de um serviço público encarregado da prestação jurisdicional, arbitrando conflitos e garantindo direitos" (BRASIL. Tribunal de Contas da União. Acórdão 1.295/2015 (FiscJudiciário) - TCU - Plenário, Rel. Min. José Múcio Monteiro, sessão de 27.5.2015, p. 3-4).

4 A Justiça Militar utiliza-se em parte da estrutura e dos juízes estaduais, não sendo o caso de detalhar este aspecto. Escrevi sobre o tema em $A$ autonomia financeira do Poder Judiciário (2016), p. 41-51. 
brasileira de burocrática para gerencial, fomentaram várias medidas no âmbito da administração pública, inclusive no Poder Judiciário, resultando, dessa evolução, a Emenda Constitucional n. $45 .^{5}$

Com a Emenda Constitucional n. 45, de 2004, pela introdução do inc. I-A aos arts. 92 e 103-B, foi criado o Conselho Nacional de Justiça, com a função de exercer "o controle da atuação administrativa e financeira do Poder Judiciário", inerente ao qual está a atividade de planejamento, imprescindível para a boa gestão dos tribunais.

Como já ressaltado em texto de minha autoria, há órgãos da administração pública dotados de tal dimensão que tornam imprescindível, ainda que integrando um ente federado, seguir as mesmas exigências a que somente estes últimos estejam formalmente sujeitos, sendo, nessa situação, o Poder Judiciário um exemplo claro:

"Somadas essas e outras circunstâncias à dimensão de alguns órgãos da administração pública, esta só poderá ser eficiente se as técnicas de planejamento forem aplicadas também a esses órgãos, especialmente aqueles dotados de alto grau de autonomia, em que se torna pouco viável a imposição de normas e procedimentos. É o caso, por exemplo, dos Poderes da República, dos Ministérios Públicos e dos Tribunais de Contas". ${ }^{6}$

Em valores da época (2009), cuja proporção não sofreu significativas alterações, mostrou-se que o Poder Judiciário do Estado de São Paulo administra recursos que equivalem e, por vezes, até mesmo superam o de vários entes da Federação, inclusive Estados, como Alagoas, Sergipe, Piauí, Rondônia e Roraima, e de muitos dos mais importantes Municípios, como Curitiba, Fortaleza, Recife, além de órgãos públicos, como o Senado Federal:

"Apenas para que se tenha uma noção, o Poder Judiciário do Estado de São Paulo administra um montante de recursos da ordem de R \$ 5.176.147.300,00 (Lei Estadual n. 13.916, de 22.12.2009), volume que equivale e muitas vezes supera o de vários entes da Federação, inclusive Estados-membros (Alagoas, com R \$ 5,7 bilhões; Sergipe, com R \$ 5,2 bilhões - Lei n. 6.568; Piauí, com R \$ 4,6 bilhões - Lei n. 5.832;

5 Como bem ressaltado pelo Tribunal de Contas da União no Relatório Sistêmico da Função Judiciária (Fisc Judiciário): "Com as inovaçôes trazidas pela emenda, houve uma mudança de paradigma na gestão do Poder Judiciário brasileiro, mediante a implantação de ações estratégicas, as quais visaram o planejamento, o controle e a implantação de novas políticas judiciárias" (BRASIL. Tribunal de Contas da União. Acórdão 1.295/2015(Fisc-Judiciário) - TCU Plenário, Rel. Min. José Múcio Monteiro, sessão de 27.5.2015, p. 4).

6 CONTI, José Mauricio. Planejamento e responsabilidade fiscal, p. 52. 
Rondônia, com R \$ 4,1 bilhões - Lei n. 2.009; Roraima, com R \$ 1,5 bilhões - Lei n. 701) e de muitos dos mais importantes municípios (Curitiba, com $\mathrm{R} \$ 3,7$ bilhôes Lei n. 13.073; Fortaleza, com R \$3,4 bilhōes - Lei n. 9.440; Recife, com R \$ 2,3 bilhões - Lei n. 17.509), bem como de relevantes órgãos públicos (Senado Federal, com R\$ 2,7 bilhões)"?

Em valores exemplificativos, constata-se que os dados são cada vez mais expressivos: enquanto o Tribunal de Justiça de São Paulo, em dados do período 20152016, tem orçamento da ordem de $\mathrm{R} \$ 10$ bilhōes (Orçamento de 2016 - Lei $\mathrm{n}$. 16.083/2015), o Estado de Alagoas prevê orçamento de R \$ 8,4 bilhões para 2016; Sergipe, R \$ 8,3 bilhões; Piauí, R \$ 11,3 bilhões; Rondônia, R \$ 6,6 bilhões; e Roraima 3,3 bilhōes; cidades como Curitiba, $\mathrm{R} \$ 8,3$ bilhões, Fortaleza, $\mathrm{R} \$ 7,2$ bilhões, e Recife, R \$ 5,9 bilhões; e órgãos como a Câmara dos Deputados, R \$ 5,3 bilhões, Senado Federal, R \$ 5,3 bilhōes, e o Ministério Público da União, R \$ 5,6 bilhôes (todos dados orçamentários de 2016). ${ }^{8}$

Diante desse quadro, não há racionalidade em se exigir que entes da federação de dimensões diminutas, como o caso de pequenos Municípios, estejam sujeitos a um ordenamento jurídico que lhes exija a elaboração e execução do Plano Plurianual, da Lei de Diretrizes Orçamentárias e da Lei Orçamentária Anual e, por sua vez, órgãos de grandes dimensões, como é o caso do Tribunal de Justiça do Estado de São Paulo, não se vejam obrigados a manter um sistema de planejamento orçamentário.

Torna-se evidente a necessidade de que órgãos públicos da relevância administrativa dos tribunais adotem sistemas próprios de planejamento orçamentário, como destacados nas palavras de autores que trataram do tema e bem observaram o problema.' Rêmolo Letteriello, desembargador e ex-presidente do Tribunal de Justiça do Mato Grosso do Sul, mostra a necessidade de um plano plurianual para aquela Corte, que teria a finalidade, inclusive, de permitir um maior acompanhamento das ações desenvolvidas por aquele Poder - ações que, promovidas de maneira desconexa e sem plano, ficam alheias a formas eficazes de controle. ${ }^{10}$ No mesmo sentido, manifesta-se o juiz Edivan Rodrigues Alexandre, do Estado da Paraíba. ${ }^{11}$

CONTI, José Mauricio. Planejamento e responsabilidade fiscal, p. 52-53.

8 CONTI, José Mauricio. Planejamento estratégico do Poder Judiciário. In CONTI, José Mauricio (Org.). Poder Judiciário: orçamento, gestão e políticas públicas, p. 67-93.

9 CONTI, José Mauricio. Planejamento e responsabilidade fiscal, p. 52-53.

10 LETTERIELLO, Rômulo. O orçamento e a administração dos tribunais. Revista CEJ, p. 108115.

11 ALEXANDRE, Edivan R. Plano Plurianual para a administração do Poder Judiciário. Associação do Magistrados da Paraíba. 
Em 2008, o Tribunal de Contas da União, ao realizar levantamento de auditoria para avaliar a situação da governança de tecnologia da informação na administração pública federal, identificou a ausência de planejamento estratégico institucional, o que se mostra fundamental para a modernização da gestão, como deixa claro:

"17. O contexto atual de intensas mudanças faz com que as organizações tenham que se adaptar rapidamente às alterações do ambiente em que atuam. No entanto, há organizações que ainda atuam de maneira reativa, apenas respondendo às demandas geradas por essas mudanças. Há gestores que ainda acreditam ser impossível definir estratégias de ação devido à rapidez e à constância dessas mudanças. 18. Dentro desse cenário de instabilidade, o planejamento tem se tornado cada vez mais importante e vital e deve ser construído de maneira flexível, com o engajamento e comprometimento de todos os colaboradores da organização. As organizaçóes que não planejam correm riscos de não alcançarem os objetivos desejados. Com uma visão de futuro estabelecida, as organizações poderão se adaptar às constantes mudanças que ocorrem na sua área de atuação e agilizar seu processo de tomada de decisões. 19. O planejamento estratégico torna-se uma importante ferramenta para a tomada de decisão e faz com que os gestores estejam aptos a agir com iniciativa, de forma proativa, contra as ameaças e a favor das oportunidades identificadas nas constantes mudanças que ocorrem". ${ }^{12}$

E recomendou expressamente ao Conselho Nacional de Justiça e ao Conselho Nacional do Ministério Público que "promovam ações com o objetivo de disseminar a importância do planejamento estratégico, procedendo, inclusive mediante orientação normativa, ações voltadas à implantação e/ou aperfeiçoamento de planejamento estratégico institucional". ${ }^{13}$

Por todas essas razões, o Poder Judiciário passou a dar atenção ao tema, e o Conselho Nacional de Justiça, no exercício de sua competência de controle da atuação administrativa e financeira de todo o Poder Judiciário, comandou o debate sobre o assunto, que veio a ser objeto de discussão no Segundo Encontro Nacional do Judiciário, ocorrido em fevereiro de 2009, em Belo Horizonte.

Nesse evento, foram estabelecidas dez metas nacionais a serem alcançadas pelo Poder Judiciário em 2009, sendo a primeira delas, justamente, "desenvolver e/ou alinhar planejamento estratégico plurianual (mínimo de 05 anos) aos objetivos estratégicos do Poder Judiciário, com aprovação no Tribunal Pleno ou Órgão Especial”, ${ }^{4}$ o que se concretizou com a Resolução CNJ n. 70, de 18 de março de 2009. ${ }^{15}$

12 BRASIL. Tribunal de Contas da União. Acórdão 1.603/2008 - TCU - Plenário, Rel. Min. Guilherme Palmeira, sessão de 13.8.2008, p. 4.

13 BRASIL. Tribunal de Contas da União. Acórdão 1.603/2008 - TCU - Plenário, Rel. Min. Guilherme Palmeira, sessão de 13.8.2008, recomendação 9.1.1.

14 Disponível em: <www.tj.sp.gov.br/noticias, notícia datada de 27.2.2009>. Acesso em: 12 mar. 2009.

15 CONTI, José Mauricio. Planejamento e responsabilidade fiscal, p. 52-53. 
O Poder Judiciário forma um todo coeso, a ser considerado sob o aspecto de uma organização única, independentemente de sua estrutura se desdobrar no âmbito das unidades em que se compõem a federação brasileira, especialmente no que tange ao planejamento, como bem ressaltou o Ministro do Supremo Tribunal Federal e Professor Ricardo Lewandowski: "Mas para isso é preciso, antes de tudo, que o nosso Judiciário, dividido entre as várias instâncias e Justiças especializadas, se transforme em um Judiciário Nacional, dotado de um projeto comum, concebido democraticamente, a partir da audiência de todos os seus integrantes, sem prejuízo das autonomias locais e do próprio princípio federativo". ${ }^{16}$

Daí a razão de ser necessário que esses órgãos se coordenem entre si, de modo que sigam estratégias, diretrizes e objetivos próprios do Poder Judiciário, independentemente do fato de integrarem outros entes federados.

Isso exigirá que se tenha um planejamento do Poder Judiciário de natureza indicativa, sob o comando do Conselho Nacional de Justiça, ${ }^{17}$ com abrangência nacional, mas dotado de uma clara delimitação dessa atribuição, tendo em vista a impossibilidade de interferir na autonomia dos tribunais de forma a caracterizar violação ao princípio federativo e mesmo à separação de poderes.

Nesse contexto, não há como aceitar que esse planejamento tenha detalhamento orçamentário, uma vez que isso ultrapassará os limites de suas atribuições, por não ser compatível a fixação de ações governamentais específicas e respectivas dotaçôes que vincule o orçamento, por exemplo, de um tribunal estadual, que integra ente da federação com autonomia para estabelecer seu próprio orçamento - e também planejamento orçamentário, no qual está inserido o respectivo Poder Judiciário. Mas é imprescindível que esse planejamento se materialize nos orçamentos, de forma alinhada, coesa, para que se transforme em medidas concretas. ${ }^{18}$

O Conselho Nacional de Justiça, no exercício de suas funções nesse campo, destacou-se inicialmente com a Resolução CNJ n. 49, de 18 de dezembro de 2007, que determinou aos tribunais a criação de núcleos de estatística e gestão estratégica, "primeiro passo para a institucionalização de um sistema de planejamento, que

16 LEWANDOWSKI, Enrique R. Planejamento estratégico do Poder Judiciário. Revista Justiça \& Cidadania, p. 19.

17 Órgão com competência para esta finalidade, conforme o art. 103-B, $\$ 4^{\circ}$, da Constituiçãao.

18 O alinhamento do orçamento dos tribunais, incluída a parte que lhe cabe no plano plurianual do ente da federação, já é um passo importante. Alguns tribunais já dispõem de normas específicas nesse sentido, consoante se constata da Resolução n. 97/2009, do Conselho da Justiça Federal, que, ao regular o planejamento estratégico no âmbito da Justiça Federal, prevê, em seu art. 5\%, que "O planejamento orçamentário deve estar alinhado ao planejamento estratégico, a fim de garantir os recursos necessários para alcançar os resultados esperados”. 
depende, para sua elaboração e acompanhamento, de informações úteis, precisas e atualizadas, com as quais serão fixadas e implementadas as diretrizes para o avanço na gestão dos tribunais", uma vez que a "existência de dados confiáveis, em quantidade e qualidade adequadas, é a base sobre a qual se sustenta todo o sistema de gestão e, por consequência, o planejamento, já que não se é possível administrar o que não se conhece", e permite também a precisa identificação dos objetivos a serem alcançados, a escolha de indicadores adequados, o estabelecimento de metas e todos os demais elementos imprescindíveis para que o planejamento produza os efeitos almejados. ${ }^{19}$

Em 2009, a Resolução n. 70, de 18 de março, em consonância com o que se está expondo, instituiu o "Planejamento Estratégico do Poder Judiciário", que se consolidou no "Plano Estratégico Nacional", determinando aos tribunais do País que elaborem seus respectivos planejamentos estratégicos, alinhados ao Plano Estratégico Nacional fixado na referida resolução, com periodicidade mínima de cinco anos, adotando como metodologia o Balanced Scorecard (BSC), com previsão da missão, da visão e os atributos de valor do Judiciário para a sociedade.

Isso representou, como já escrevi anteriormente, "o início de uma nova e importante fase no planejamento da ação governamental, que é a transposição das técnicas de planejamento orçamentário, financeiro e administrativo para órgãos da administração pública”, compatíveis com uma sociedade moderna que se torna cada vez mais dinâmica, e exige uma administração competente, com ações eficientes, eficazes e efetivas, ${ }^{20} \mathrm{e}$, ao institucionalizar a obrigatoriedade de um planejamento estratégico plurianual para todo o Poder Judiciário, evidenciou a importância e relevância do planejamento na administração pública, a ser aplicado não apenas ao ente da Federação, mas também aos órgãos que o integram, no caso, o Poder Judiciário. ${ }^{21}$

As justificativas constantes da referida resolução mostram com clareza as razões motivadoras da instituição do planejamento estratégico plurianual. Reconhece-se haver uma unicidade do Poder Judiciário, que exige "a implementação de diretrizes nacionais para nortear a atuação institucional de todos os seus órgãos”, bem como "a necessidade de se conferir maior continuidade administrativa aos tribunais, independentemente da alternância de seus gestores". No caso do Poder Judiciário, essa necessidade mostra-se ainda mais relevante, na medida em que os cargos de

19 CONTI, José Mauricio. Planejamento estratégico do Poder Judiciário, p. 74.

20 CONTI, José Mauricio. Planejamento e responsabilidade fiscal, p. 52-53.

21 CONTI, José Mauricio. Planejamento e responsabilidade fiscal, p. 52-53. 
direção são ocupados por mandatos de apenas dois anos, ${ }^{22}$ o que inviabiliza qualquer continuidade administrativa se não houver um plano previamente definido e eficaz que dê sustentação à administração, independentemente do gestor do momento.

O Planejamento Estratégico proposto pela Resolução n. 70 foi estruturado em quatro componentes:

a) a Missão, que é realizar justiça;

b) a Visão, que é "ser reconhecido pela Sociedade como instrumento efetivo de justiça, equidade e paz social";

c) os Atributos de Valor do Judiciário para a Sociedade, que são credibilidade, acessibilidade, celeridade, ética, imparcialidade, modernidade, probidade, responsabilidade social e ambiental e transparência; e

d) quinze objetivos estratégicos, distribuídos em oito temas. ${ }^{23}$ Destes, cabe destaque, por terem vinculação mais estreita com o objeto desta tese, o tema "Alinhamento e integração", com dois objetivos ("Garantir o alinhamento estratégico em todas as unidades do Judiciário" - objetivo 6; e "Fomentar a interação e a troca de experiências entre Tribunais nos planos nacional e internacional" - objetivo 7), e o tema "Orçamento", com um único objetivo, "Assegurar recursos orçamentários necessários à execução da estratégia" - objetivo 15.

Os planejamentos estratégicos formulados pelos tribunais devem conter ao menos um indicador de resultado para cada objetivo estratégico e metas de curto,

22 Conforme estabelecido na Lei Orgânica da Magistratura - LOMAN (Lei Complementar n. 35, de 14 de março de 1979).

23 A saber: a) Eficiência operacional, com dois objetivos: 1 (garantir a agilidade nos trâmites judiciais e administrativos) e 2 (buscar a excelência na gestão dos custos operacionais); b) Acesso ao Sistema de Justiça, com dois objetivos: 3 (facilitar o acesso à Justiça) e 4 (promover a efetividade no cumprimento das decisóes); c) Responsabilidade Social, com o objetivo 5 (promover a cidadania); d) Alinhamento e Integração, com dois objetivos: 6 (garantir o alinhamento estratégico em todas as unidades do Judiciário) e 7 (fomentar a interação e a troca de experiências entre Tribunais nos planos nacional e internacional); e) Atuação Institucional, com três objetivos: 8 (fortalecer e harmonizar as relações entre os Poderes, setores e instituições), 9 (disseminar valores éticos e morais por meio da atuação institucional efetiva) e 10 (aprimorar a comunicação com públicos externos); f) Gestão de Pessoas, com dois objetivos: 11 (desenvolver conhecimentos, habilidades e atitudes dos magistrados e servidores) e 12 (motivar e comprometer magistrados e servidores com a execução da estratégia); g) Infraestrutura e Tecnologia, com dois objetivos: 13 (garantir a infraestrutura apropriada às atividades administrativas e judiciais) e 14 (garantir a disponibilidade de sistemas essenciais de tecnologia de informação); e h) Orçamento, com o objetivo 15 (assegurar recursos orçamentários necessários à execução da estratégia). 
médio e longo prazos $^{24}$ associadas aos indicadores de resultados, com os projetos e as ações suficientes e necessários para atingir as metas fixadas (Res. CNJ n. $70 / 2009$, art. $2^{\circ}, \$ 1^{\circ}$ ).

Referida Resolução instituiu o Plano Estratégico Nacional (Anexo I), ao qual ficam subordinados os planejamentos estratégicos de todos os tribunais do país, que a ele deverão se adequar (Res. CNJ n. 70/2009, art. 2o, $\$ 2^{\circ}$ ).

A Resolução foi cumprida por todos os tribunais do país, que instituíram os respectivos planejamentos estratégicos, entre os quais está o Tribunal de Justiça do Estado de São Paulo, ao qual será feita referência de forma mais detalhada, o que se justifica por integrar o ente da federação do qual fazemos parte, cujo orçamento é objeto de estudo e referência em outros itens do trabalho, bem como por estar entre aqueles que têm maior dimensão em termos de órgão da administração pública, especialmente no aspecto orçamentário.

Posteriormente, findo o prazo quinquenal estabelecido pela Resolução n. 70, de 2009, o Conselho Nacional de Justiça editou a Resolução n. 198, de $1^{\circ}$ de julho de 2014, que atualizou e aperfeiçoou o Planejamento Estratégico, estabelecendo a "Estratégia Nacional do Poder Judiciário para o sexênio 2015-2020", a qual, além de aumentar o prazo para seis anos, trouxe uma série de novas determinações, ora sintetizadas. É interessante notar a pouca relevância que foi dada pela mídia e também pelos tribunais à edição da Resolução n. 198/2014, praticamente não divulgada e comentada, diferentemente do que ocorreu com a Resolução n. 70/2009, evidenciando uma visível perda de interesse no planejamento estratégico do Poder Judiciário, o que prejudica a sua efetividade, pela redução do engajamento institucional no tema, que é imprescindível em matéria de planejamento, sob pena de suas normas terem uma função meramente burocrática, sem promoverem o necessário incentivo aos atores envolvidos na perseguição dos objetivos, resultados e metas.

O prazo mínimo passou a ser de seis anos e introduziu-se, além da missão, visão e valores, ${ }^{25}$ o conceito de "macrodesafios do Poder Judiciário", que torna mais

24 Neste ponto, há que se fazer um pequeno reparo. A generalidade dos estudos admite sendo médio prazo o período entre três e cinco anos, como já mencionamos anteriormente. No caso do planejamento estratégico do Poder Judiciário, a Resolução CNJ n. 70/2009 refere-se a um planejamento estratégico por um período mínimo de cinco anos. Sendo assim, metas de longo prazo se justificam apenas para aqueles tribunais que tenham formulado planejamentos estratégicos por períodos significativamente superiores a cinco anos, não sendo o caso de incluir o prazo estabelecido pela Resolução CNJ n. 198/2014, de seis anos.

25 Missão "realizar Justiça" ("Fortalecer o Estado Democrático e fomentar a construção de uma sociedade livre, justa e solidária, por meio de uma efetiva prestação jurisdicional”); Visão "ser reconhecido pela sociedade como instrumento efetivo de justiça, equidade e paz social” ("Ter 
claras as principais questôes a serem enfrentadas; as metas foram detalhadas em Metas de Duração Continuada (MDC), Metas de Medição Periódica (MMP) e Metas Nacionais ( $\mathrm{MN})$; deverão também os tribunais organizarem seus planejamentos estratégicos estabelecendo as Iniciativas Estratégicas Nacionais (IEN), as Diretrizes Estratégicas (DE), bem como as "cestas de indicadores e iniciativas estratégicas”. A Estratégia Judiciário 2020 poderá ser alinhada em três níveis de abrangência: nacional, por segmento de justiça e por órgão do Judiciário, ${ }^{26}$ o que, como já destacado em texto de minha autoria, permite

"aperfeiçoar a difícil compatibilização entre a unidade do Poder Judiciário no âmbito nacional, que é necessária, especialmente no que tange ao planejamento, a fim de manter uma uniformidade de propósitos do Poder Judiciário como um todo; e, de outro lado, o respeito à autonomia e independência dos tribunais, necessária para fazer valer não só o princípio da separação de poderes, como também a autonomia dos entes federados, já que há muitos - a maior parte - tribunais estaduais, integrando entes autônomos, por força do princípio federativo". ${ }^{27}$

Destaque ainda deve ser dado à Rede de Governança Colaborativa do Poder Judiciário, coordenada pelo CNJ, com participação dos tribunais e todos os segmentos de justiça, a quem compete apresentar propostas de aperfeiçoamento da Estratégia Judiciário 2020 e auxiliar a execução e o monitoramento dos trabalhos e da divulgação dos resultados. ${ }^{28}$ Foram estabelecidos 13 macrodesafios, integrando três perspectivas (sociedade, processos internos e recursos), visando à maior efetividade na prestação jurisdicional. Evidentemente, em se tratando de norma de caráter nacional, sem relação com recursos orçamentários. Mas a preocupação orçamentária aparece claramente na "perspectiva recursos", em que se estabelecem quatro macrodesafios que se voltam a melhorar a administração financeira, destacando-se o "aperfeiçoamento da gestão de custos" e a "instituição da governança judiciária".

Como se poderá observar, não são simples os ajustes que devem ser feitos para alinhar e compatibilizar os sistemas e normas de planejamento aos quais o Poder Judiciário precisa se submeter, o que, evidentemente, causa dificuldades não somente administrativas, mas também jurídicas.

credibilidade e ser reconhecido como um Poder célere, acessível, responsável, imparcial, efetivo e justo, que busca o ideal democrático e promove a paz social, garantindo o exercício pleno dos direitos de cidadania"); e Atributos de Valor para a Sociedade a "credibilidade, acessibilidade, celeridade, ética, imparcialidade, modernidade, probidade, responsabilidade socioambiental e transparência e controle social".

26 Resolução CNJ n. 198/2014, art. 3º.

27 CONTI, José Mauricio. Planejamento estratégico do Poder Judiciário, p. 78.

28 Resolução CNJ n. 198/2014, art. 11. 
Em âmbito federal, no que se refere ao planejamento orçamentário do Poder Judiciário, para exemplificar com dados do PPA federal 2012-2015, cabe destaque aos programas 1389 (Controle da atuação administrativa e financeira do Poder Judiciário), 0565 (Prestação jurisdicional do Supremo Tribunal Federal), 0566 (Prestação jurisdicional militar), 0567 (Prestação jurisdicional no Distrito Federal), 0568 (Prestação jurisdicional no Superior Tribunal de Justiça), 0569 (Prestação jurisdicional na Justiça Federal), 0570 (Gestão do processo eleitoral) e 0571 (Prestação jurisdicional trabalhista). O PPA federal 2016-2019 manteve a mesma estrutura programática, que é reproduzida nas leis orçamentárias anuais.

Nota-se haver na esfera federal praticamente um programa para cada um dos ramos do Poder Judiciário, o que aumenta o grau de discricionariedade dos gestores principais, evitando maiores entraves burocráticos na administração dos recursos. Trata-se, na hipótese, de medida que se compatibiliza com a autonomia financeira constitucionalmente assegurada ao Poder Judiciário, por permitir maior liberdade ao gestor e menor interferência dos outros poderes. Contudo, diminui o grau de impositividade do planejamento, bem como da lei orçamentária e da respectiva execução, tornando menos seguras as previsões nela contidas, dada a maior flexibilidade dos gastos.

Ver-se-á que a situação não difere significativamente do que se encontrará nas Justiças dos Estados.

Com isso, assume maior relevância o planejamento próprio dos Tribunais, uma vez que nele serão mais bem detalhados as diretrizes, os objetivos e as metas que seguirão no período do plano estabelecido.

Mesmo assim, não se consegue viabilizar perfeitos alinhamento, coesão e coerência das normas que materializam o planejamento do Poder Judiciário, dadas as dificuldades que se evidenciam presentes, como se pode constatar pela análise dos planos plurianuais federais já referidos (2012-2015 e 2016-2019) e de alguns planejamentos estratégicos de tribunais que integram o sistema de justiça federal. As diferentes metodologias dos documentos que resultam em cada um deles não facilitam a integração, de modo que a atividade planejadora e os gestores ficam sujeitos a diferentes perspectivas, o que evidentemente gera incertezas e inseguranças quanto à forma de agir.

A Justiça do Trabalho, que apresenta grandes dimensões como órgão da administração pública federal, movimenta elevada quantidade de recursos, por exemplo, prevê, no PPA 2016-2019, no referido programa 0571 (Prestação Jurisdicional Trabalhista), o valor total para o período de $\mathrm{R} \$$ 63.406.822.000,00, sendo $\mathrm{R} \$ 14.352 .781 .000,00$ para o ano de 2016 e $\mathrm{R} \$ 49.054 .041 .000,00$ para os anos de 2017 a 2019. Na lei orçamentária federal, consta o montante de $\mathrm{R} \$ 13.471 .609 .006 .000,00$ para o programa da LOA 2016 “0571 - Prestação Jurisdicional Trabalhista”, que se desdobra em 97 ações, como pagamento de pessoal (ação "20TP - Pessoal Ativo da Uniāo”, com 
dotação de R \$ 9.312.569.519,00, por exemplo), dezenas de construções de edifícios-sede de varas do trabalho (como a ação "134H - Construção do Edifício-Sede do Tribunal Regional do Trabalho da 5a Região em Salvador-BA", com dotação de R\$ 70.127.273,00), pagamentos de benefícios assistenciais, contribuiçôes para o regime de previdência, reformas e ampliações de edifícios, formação e aperfeiçoamento de servidores, manutenção de sistemas de informação, assistência médica, entre outras.

O Plano Estratégico da Justiça do Trabalho 2015-202029 tem outro enfoque, como se pode constatar. Após estabelecer a missão, a visão e os valores, e os objetivos estratégicos, estes nas perspectivas "recursos", "processos internos" e "sociedade", define os indicadores e as metas, em número de treze. A análise do documento permite verificar que nele há uma preocupação com o aspecto orçamentário, ${ }^{30}$ sem ser um documento de natureza orçamentária, uma vez que não há a alocação dos valores para o que estabeleceu como indicadores e metas. A preocupação com o orçamento fica clara nos indicadores da Justiça do Trabalho, na "Perspectiva Recursos", que prevê "Aperfeiçoar a gestão de custos", e fixa como Meta 2 "aumentar Índice de Execução do Orçamento Disponibilizado (IEOD)". Em outras metas, as dotações orçamentárias não integram os indicadores e metas, como se pode constatar de alguns exemplos. É o caso da Meta 4, "Reduzir o prazo médio, em relação ao ano base de 2014" (referindo-se ao tempo médio de duração do processo em $2^{\mathrm{a}}$ instância TMDP2); da Meta 5, "Reduzir o prazo médio, em relação ao ano base de 2014" (tempo médio de duração do processo - $1^{\text {a }}$ instância - fase de conhecimento TMDP1c); Meta 6, "Julgar quantidade maior de processos de conhecimento do que os distribuídos no ano corrente"; Meta 7, "Identificar e julgar, até 31.12.2016, pelo menos 90\% dos processos distribuídos até 31.12.2014, nos 10 e 2o graus"; Meta 9, "Aumentar o índice de conciliação na fase de conhecimento, em relação à média do biênio 2013/2014, em 6 pontos percentuais, até 2020"; e de forma semelhante nas outras metas. Vê-se que no PPA e na LOA fica clara a natureza orçamentária dos referidos documentos, com a previsão das ações que integram os programas definin-

29 Resolução CSJT n. 145, de 28 de novembro de 2014, que prevê revisão anual (art. 20). A Resolução CSJT n. 157, de 27 de novembro de 2015, aprovou a revisão, atualizando para o período de 2016 a 2020, e o Conselho Superior da Justiça do Trabalho produziu o documento ReuneJT - Plano Estratégico da Justiça do Trabalho 2015-2020 - 1a Revisão Técnica 2015, dos quais foram extraídas as informações que seguem.

30 A Resolução CNJ n. 70/2009, art. 1, IV, “h”, estabeleceu como Objetivo (número 15) "assegurar recursos orçamentários necessários à execução da estratégia”, e o art. $2^{\circ}, \S 3^{\circ}$, determina que "As propostas orçamentárias dos tribunais devem ser alinhadas aos seus respectivos planejamentos estratégicos, de forma a garantir os recursos necessários à sua execução". A Resolução CNJ n. 198, de 2014, em seu art. 4º, dispõe que "As propostas orçamentárias dos tribunais devem ser alinhadas aos seus respectivos planos estratégicos, de forma a garantir os recursos necessários à sua execução", reproduzindo o art. 20, $\$ 3^{\circ}$, da Resolução CNJ n. 70 ora referida. 
do os exatos valores que a elas se destinam. No caso do "plano estratégico" da Justiça do Trabalho, a natureza é gerencial, não havendo a definição dos valores que se pretende destinar para o cumprimento das metas. Como se expôs, fica o órgão sujeito a um planejamento materializado em lei, que é o PPA e a LOA, e a outro de natureza infralegal, o planejamento estratégico, cujas metodologias diferem e estabelecem caminhos distintos para alcançar os objetivos a que se propõe, exigindo um esforço gerencial para que se compatibilizem; pecam, no entanto, pela falta de clareza que acaba resultando desse não alinhamento, dificultando a ação do gestor.

A situação não é muito diversa em outro ramo de grandes dimensões na administração pública federal, como a Justiça Federal ordinária.

O Plano Plurianual federal 2012-2015, para usarmos como exemplo, prevê o programa “0569 - Prestação Jurisdicional na Justiça Federal”, cujo valor total é de R\$ 26.838.837.000,00, sendo $\mathrm{R} \$$ 6.456.523.000,00 para o ano de 2012 e $\mathrm{R} \$$ 20.382.313.00,00 para o período de 2013 a 2015. No plano plurianual 2016-2019, o programa permaneceu o mesmo, e os números são: total de $\mathrm{R} \$ 40.595 .382 .000,00$, sendo $\mathrm{R} \$ 9.203 .380 .000,00$ para o ano de 2016 e $\mathrm{R} \$ 31.392 .002 .000,00$ para o período de 2016 a 2019. Na LOA para 2016, consta o montante de $\mathrm{R} \$ 8.730 .576 .370,00$ para o programa "0569 - Prestação Jurisdicional na Justiça Federal”, que se desdobra em 81 ações, como pagamento de pessoal (ação "20TP - Pessoal Ativo da União", com dotação de $\mathrm{R} \$$ 5.677.670.205,00, por exemplo), construções de edifícios-sede de varas, tribunais e seções judiciárias da Justiça Federal (como a ação "11RV - Construção do Edifício-Sede do Tribunal Regional Federal da 1a Região em Brasília-DF”, com dotação de $\mathrm{R}$ \$ 21.612.187,00), aquisições, reformas e ampliações de edifícios (como a ação "15HF - Aquisição de imóveis pra funcionamento do TRF da 3a Região em São Paulo - SP - Unidade 'F”'), pagamentos de benefícios assistenciais, contribuições para o regime de previdência, entre outras.

O planejamento estratégico da Justiça Federal Ordinária, aprovado pela Resolução CJF n. 313, de 22 de outubro de 2014, com o anexo "A estratégia da Justiça Federal 2015-2020", e alteraçóes posteriores estabeleceram o Plano Estratégico da Justiça Federal (PEJF) e o Plano Estratégico da Informação (PETI), estabelecendo-se (limitando-se ao Plano Estratégico da Justiça Federal) a missão, a visão de futuro e os valores, identificando-se os macrodesafios e respectivos objetivos estratégicos, e, em cada um deles, os indicadores, as metas e as iniciativas correspondentes, sendo estas últimas desdobradas em programas, projetos e ações. ${ }^{31}$

31 Observe-se que essas expressões não são usadas de forma uniforme aos demais documentos de planejamento governamental, nem os conceitos correspondem exatamente aos que têm sido utilizados no âmbito federal, mesmo nos PPA, não havendo no documento explicação que detalhe o exato significado das expressões. 
Apenas para mencionar alguns exemplos em caráter ilustrativo, o primeiro deles, sob a "Perspectiva Sociedade", estabelece o Macrodesafio do Poder Judiciário "Garantia dos diretos de cidadania", com um objetivo estratégico, "Buscar a satisfação do usuário/cidadão", com o qual se pretende "prestar serviços de qualidade na busca da satisfação dos usuários da Justiça Federal, de modo a assegurar os direitos de cidadania”; esse objetivo estratégico prevê um indicador (taxa de satisfação dos usuários da Justiça Federal), uma meta (atingir 70\% de satisfação dos usuários da Justiça Federal em 2020) e uma iniciativa (carta de serviços). Outro macrodesafio que releva destacar, dada sua relevância, está na "Perspectiva Processos Internos" e consiste na "Celeridade e produtividade na prestação jurisdicional”, sendo seu objetivo estratégico "Agilizar os trâmites judiciais", voltando-se a "tornar a prestação jurisdicional mais ágil, com vistas à razoável duração do processo, mediante a implementação de açôes que propiciem o aumento da produtividade de magistrados e servidores sem prejuízo da segurança jurídica e procedimental". Nesse caso, foram estabelecidos quatro indicadores e as respectivas metas, para os quais foram previstas três iniciativas, na forma do quadro a seguir: ${ }^{32}$

\begin{tabular}{|c|c|c|}
\hline Indicador & Meta & Iniciativa \\
\hline $\begin{array}{l}\text { Índice de produtividade } \\
\text { judicante }\end{array}$ & $\begin{array}{l}\text { Julgar quantidade maior de processos de } \\
\text { conhecimento do que os distribuídos no ano. }\end{array}$ & $\begin{array}{l}\text { Processo Judicial } \\
\text { Eletrônico da JF (PJe). }\end{array}$ \\
\hline $\begin{array}{l}\text { Índice de julgamento } \\
\text { de processos antigos }\end{array}$ & $\begin{array}{l}\text { Identificar e julgar, no ano corrente, pelo menos } \\
100 \% \text { dos processos distribuídos até } 31 / 12 \text { do } \\
\text { quinto ano anterior ao ano corrente, no } 1^{\circ} \text { e } \\
2^{\circ} \text { graus; } 100 \% \text { dos distribuídos até } 31 / 12 \text { do } \\
\text { quarto ano anterior ao ano em curso; e } 70 \% \text { dos } \\
\text { distribuídos até } 31 / 12 \text { do antepenúltimo ano nos } \\
\text { juizados especiais federais e turmas recursais. }\end{array}$ & $\begin{array}{l}\text { Implantação do } \\
\text { Modelo Nacional de } \\
\text { Interoperabilidade (MNI). }\end{array}$ \\
\hline $\begin{array}{l}\text { Índice de julgamento } \\
\text { de processos antigos }\end{array}$ & $\begin{array}{l}\text { Aumentar o índice de produtividade de } \\
\text { magistrados em relação à média do triênio } \\
\text { anterior da própria região. (Média da } \\
\text { produtividade dos três anos anteriores em } \\
\text { relação ao ano em mensuração). }\end{array}$ & \multirow{3}{*}{$\begin{array}{l}\text { Estudos sobre a } \\
\text { atratividade para ingresso } \\
\text { e permanência nas } \\
\text { carreiras da magistratura } \\
\text { federal e de servidores. }\end{array}$} \\
\hline $\begin{array}{l}\text { Índice de produtividade } \\
\text { dos servidores }\end{array}$ & $\begin{array}{l}\text { Aumentar o índice de produtividade dos } \\
\text { servidores em relação à média do triênio anterior } \\
\text { da própria região. (Média da produtividade } \\
\text { dos três anos anteriores em relação ao ano em } \\
\text { mensuração). }\end{array}$ & \\
\hline $\begin{array}{l}\text { Taxa de } \\
\text { congestionamento }\end{array}$ & Não há meta estabelecida. & \\
\hline
\end{tabular}

Vê-se que, da mesma forma que na Justiça do Trabalho, não há a dotação orçamentária correspondente, evidenciando o caráter gerencial e estratégico do plano, e não orçamentário. O caráter orçamentário, por consequência, terá de se materializar

32 BRASIL. Conselho da Justiça Federal. A estratégia da Justiça Federal 2015/2020, p. 13. 
por ocasião da transposição do plano estratégico para as normas que materializam o planejamento orçamentário da administração pública, no caso, especialmente, o Plano Plurianual (PPA) e a Lei Orçamentária Anual (LOA).

Juridicamente, criam-se situações que exigem esforço de interpretação para que sejam compreendidas de maneira adequada. É o caso, por exemplo, do disposto na Resolução CNJ n. 198/2014, que, em seu art. 4o, estabelece que "As propostas orçamentárias dos tribunais devem ser alinhadas aos seus respectivos planos estratégicos, de forma a garantir os recursos necessários à sua execução". Sendo o CNJ órgão do Poder Judiciário de caráter nacional, suas disposições aplicam-se em âmbito administrativo aos demais tribunais do país, mas evidentemente não podem ser incompatíveis com as leis ordinárias, instrumentos jurídicos que veiculam o planejamento orçamentário da administração pública - no caso, o PPA, a LDO e a LOA. Podem, por conseguinte, criar obrigação aos tribunais para que elaborem suas propostas orçamentárias alinhadas aos respectivos planos estratégicos. No entanto, estes devem em primeiro lugar estar de acordo com a lei do plano plurianual vigente do ente da federação a que pertencem. A questão será abordada no item seguinte, ficando aqui apenas a referência para chamar a atenção ao assunto que se relaciona com o que ora se discute.

Algumas questôes adicionais surgem a partir da análise do sistema de planejamento no âmbito dos tribunais estaduais, como se poderá observar a partir das considerações a seguir, em que se analisa o Tribunal de Justiça do Estado de São Paulo, o maior do país.

O Tribunal de Justiça do Estado de São Paulo instituiu o planejamento estratégico por meio da Resolução n. 505, de 25 de novembro de 2009, ${ }^{33}$ para o período de 2010 a 2014, estabelecendo como Missão, "Distribuir Justiça", e Visão, "Ser reconhecido pela Sociedade como instrumento efetivo de Justiça, Equidade e Paz Social", e destacando como Valores a "Acessibilidade, celeridade, credibilidade, ética, imparcialidade, modernidade, probidade, responsabilidade social e ambiental e transparência”. Previu 22 objetivos, acompanhados da respectiva justificativa e da ação ou ações previstas para atingi-los. Destaca-se, pelo critério de interesse para este trabalho, o Objetivo 20, "Promover efetiva distribuição de recursos financeiros, visando garantir o cumprimento dos objetivos e metas estabelecidos, observando em sua execução os princípios norteadores da gestão pública”, cuja justificativa é "Elaborar a peça orçamentária com rigor e ao mesmo tempo com substância, demonstrando com dados estatísticos, a necessidade da verba pleiteada para que

33 Publicado no DJe de 8 de janeiro de 2010, p. 2-22. 
possam ser atendidas as metas fixadas pelo Conselho Nacional de Justiça - CNJ e o Plano Plurianual (...)", por meio da Ação 20, "Fornecer, através do Núcleo de Planejamento e Gestão, à Secretaria de Orçamento e Finanças, os dados e demonstrativos que forem necessários para o embasamento das peças orçamentárias”. O planejamento estratégico foi revisto em 2013, por meio de Resolução n. 604, de 27 de junho de $2013,{ }^{34}$ prevendo-se 12 objetivos estratégicos, decorrentes da extinção daqueles que já haviam sido cumpridos e da incorporação e revisão dos demais, de forma a melhorar as condiçóes de monitoramento, aperfeiçoando-se os indicadores, e ajustar as metas e ações propostas, para melhor suportar os objetivos estratégicos. Nessa revisão, foi excluído o Objetivo 20, "em razão de considerar o orçamento tema inerente à execução do Planejamento Estratégico". No planejamento estratégico do Tribunal de Justiça do Estado de São Paulo, não há associação a dotações orçamentárias, de modo que os objetivos e ações não contêm previsão dos recursos a lhes serem destinados - seguindo o que já se observou nos planos estratégicos dos órgãos da Justiça federal anteriormente analisados.

O ente da Federação brasileira "Estado de São Paulo", no qual está inserido o Tribunal de Justiça do Estado de São Paulo, tem este como seu principal órgão de seu Poder Judiciário, e consta do Plano Plurianual para o período de 2012 a 2015, instituído pela Lei Estadual n. 14.676, de 28 de dezembro de 2011. Nele, estão estabelecidos "as diretrizes, objetivos, indicadores, valores e metas da Administração Pública Estadual e dos demais Poderes do Estado para as despesas de capital e outras delas decorrentes e para as relativas aos programas de duração continuada" (art. 10 caput, grifos nossos). O Tribunal de Justiça do Estado de São Paulo, por consequência, está abrangido pelo PPA do Estado de São Paulo. O detalhamento do PPA 2012-2015, para exemplificar, no que tange ao Poder Judiciário, aparece no volume II (Resumo da Programação - Programas e Açôes), em que o Tribunal de Justiça (órgão número 3000) vincula-se ao Programa 303 - Processo Judiciário no Tribunal de Justiça, cujo objetivo é "implementar a prestação jurisdicional e serviços auxiliares nos trâmites dos processos de $1^{\mathrm{a}} \mathrm{e} 2^{\mathrm{a}}$ instâncias, estabelecer programas de modernidade, ampliar a estrutura do Poder Judiciário visando agilizar o atendimento aos jurisdicionados, expandir a informatização em toda a Justiça, bem como construir, reformar e equipar prédios forenses", com a justificativa da "crescente e constante demanda pelos serviços judiciários e a dificuldade de acesso à Justiça pela população carente, bem como a limitação de recursos orçamentários que gera uma prestação jurisdicional que demanda aprimoramentos", tendo como públicos-alvo o "cidadão, operadores do Direito e recursos humanos internos", utilizando como

\footnotetext{
Publicado no DJe de 3 de julho de 2013.
} 
indicadores as "ações julgadas". O programa é composto por dez ações, a saber: "comunicação institucional"; "desenvolvimento e implementação de sistemas de informação"; "diligências judiciais"; "distribuição da Justiça"; "funcionamento da Escola Paulista da Magistratura”; "infraestrutura de prédios judiciais"; "instalação de varas e câmaras digitais"; "juizados especiais"; "Justiça da infância e juventude”; e "postos judiciais de autoatendimento e Justiça itinerante".

Não difere significativamente a situação no que tange ao PPA 2016-2019, embora se veja a modificação da denominação "ação" por "produto", além de ajustes nas redações das respectivas denominações de cada um. Instituído pela Lei Estadual n. 16.092, de 28 de dezembro de 2015, contempla o Tribunal de Justiça no programa 0303 - Processo Judiciário no Tribunal de Justiça, cuja dotação total para o período é de $\mathrm{R} \$ 44.335 .689 .194,00$. Subdivide-se, dessa vez, em nove produtos $^{35}$ e respectivos indicadores e metas, sendo estas últimas as quantificações do produto medidas pelos indicadores, sem que se definam os valores das dotaçóes por produto, o que evidencia uma menor preocupação em detalhar este dado no PPA de forma específica, o que se concretizará na lei orçamentária.

Usando como exemplo a LOA 2016 do Estado de São Paulo (Lei n. 16.083/2015), esta prevê para o órgão Tribunal de Justiça (03000) um programa, já referido, que permanece o mesmo (0303 - Processo Judiciário no Tribunal de Justiça), cujo valor total da dotação é R \$ 10.067.423.277,00, com a previsão de nove ações, cada uma com a correspondente dotação. ${ }^{36}$

Vê-se haver, portanto, um planejamento orçamentário quadrienal do Tribunal de Justiça do Estado de São Paulo representado pela sua participação, como órgão integrante do Estado de São Paulo, nos planos plurianuais desse ente da Federação, expresso na parte que lhe cabe no referido documento.

35 Que são os seguintes: 1) conciliação e mediação de conflitos; 2) construção, reformas e aquisição de imóveis; 3) crianças e adolescentes assistidos em situação de vulnerabilidade; 4) cursos, treinamentos e palestras, 5) desenvolvimento de atividades correicionais; 6) matérias geradas para transparência nas ações da instituição; 7) serviços de prestação jurisdicional no primeiro e segundo grau; 8) transporte dos oficiais de justiça em diligências judiciais; e 9) unidades atendidas pelos sistemas de informação.

36 São as seguintes (Número - ação - dotação): 02.061.0303.1941 - Infraestrutura de prédios judiciais - R\$ 72.456.102,00; 02.061.0303.23 - Justiça da Infância e Juventude - R \$ 10,00; 02.061.0303.4597 - Diligências judiciais - R\$ 159.600.000,00; 02.061.0303.4826 - Distribuição da Justiça - R\$ 9.402.829.325,00; 02.061.0303.6164 - Funcionamento da Corregedoria Geral de Justiça - R \$ 240.000,00; 02.061.0303.6192 - Soluções alternativas de conflitos - R \$ 10,00; 02.061.0303.4827 - Desenvolvimento, implementação e manutenção de sistemas de informação - R \$ 415.035.129,00; 02.061.0303.4822 - Funcionamento da Escola Paulista da Magistratura - R \$ 17.165.351,00; 02.061.0303.6020 - Comunicação Institucional - R \$ 97.350,00. 
Ao mesmo tempo, o Tribunal de Justiça do Estado de São Paulo tem seu planejamento quinquenal delineado pelo planejamento estratégico por ele concebido para o período de 2010 a 2014 (Resolução n. 505/209) e sexenal para o período de 2015 a 2020 (Resolução n. 706/2015).

A análise das ações que compõem o programa que constam do PPA do Estado de São Paulo vinculado ao Tribunal de Justiça, em comparação aos objetivos estratégicos que integram o planejamento estratégico do órgão, permite reconhecer alguns pontos com significativa inter-relação, o que exige uma perfeita sintonia, a fim de evitar incongruências; em outros, essa correlação é mais frágil.

Veja-se por exemplo a ação governamental "Comunicação Institucional”. Está prevista no PPA 2012-2015 do Estado de São Paulo, integrando o programa 303 ("Processo Judiciário no Tribunal de Justiça"), tendo como produto "matérias veiculadas", estabelecida a meta de 268 unidades para este período quadrienal. No orçamento do Estado de São Paulo para 2013, a referida ação é uma das ações do programa "Processo Judiciário no Tribunal de Justiça (número 0303)", recebendo o número 02.131.0303.6020. Trata-se de ação cuja descrição é o "Aprimoramento da comunicação do Judiciário com a sociedade brasileira", sendo o produto "matérias veiculadas" mensurado em unidades, tendo previsão para o exercício de 2013 de sessenta e sete (67) unidades, a ser financiada por recursos do Tesouro do Estado, prevendo-se a dotação de $\mathrm{R} \$ 40.000,00$.

O planejamento estratégico do Tribunal de Justiça 2010-2014, em sua versão revista (Resolução n. 604/2013), prevê o objetivo estratégico 4, que consiste em "Aprimorar a comunicação institucional", cuja descrição é "Aprimorar a comunicação com públicos externos e internos, com transparência, fornecendo informações em tempo hábil, de forma clara e acessível", sendo a meta "aprimorar ao sistema de comunicação social do Tribunal de Justiça do Estado de São Paulo até 31.12.2014, com observância da Resolução n. 85/2009 do Conselho Nacional de Justiça (CNJ)". O indicador é o "percentual de melhorias implementadas em relação aos objetivos principais da Resolução CNJ n. 85/2009”, e a meta física é o percentual de $100 \%$ até $2014 .^{37}$

Nota-se uma grande similaridade entre a ação governamental prevista no PPA e o objetivo que consta do planejamento estratégico, mas não há uma identidade nos produtos, indicadores e metas, o que evidentemente só tende a gerar uma falta

BRASIL. Estado de São Paulo. Tribunal de Justiça. SEPLAN - Secretaria de Planejamento Estratégico. Revisão do Planejamento Estratégico do Tribunal de Justiça de São Paulo - Biênio 2013-2014 (Anexo), p. 35. 
de coordenação, uma vez que não há uma segurança em relação à condução da administração do órgão.

Em outros casos, há uma identidade menos significativa que a do exemplo anterior, suficiente para também gerar insegurança, sendo interessante mostrar os casos para deixar mais claras as dificuldades em coordenar os dois sistemas paralelos de planejamento.

No PPA SP 2012-2015 existe a ação "Infraestrutura de prédios judiciais", que tem como produto "obras realizadas" e a meta para o período quadrienal é onze (11). No orçamento de 2013, esta ação governamental tem o número 02.061.0303.1941, e a descrição é a "Elaboração de estudos e projetos com vistas à construção do Complexo Judiciário do Tribunal de Justiça; reforma adaptação e ampliação dos prédios e espaços físicos destinados ao Judiciário estadual, visando proporcionar uma infraestrutura adequada às suas reais necessidades". ${ }^{38}$

No planejamento estratégico 2010-2014, encontra-se o objetivo 10, "Prover a adequada infraestrutura física", cuja descrição é "Prover as unidades judiciais e administrativas de infraestrutura física adequada, visando melhoria das condições de atendimento aos usuários e de trabalho dos magistrados e servidores", com três metas. A primeira meta é "contratar obras de construção, ampliação e reforma geral referente ao Programa Fórum São Paulo até 31.12.2014, com previsão até o final de 2014 de contratação de obras de construção, ampliação e reforma geral”. A segunda meta é "desenvolver Programa de Ergonomia, identificando as unidades prioritárias do TJSP até 31.12.2014”, com previsão até o final desse período de ter o programa de ergonomia elaborado. E a terceira meta é "implantar sinalização padronizada em 90\% dos prédios do Tribunal de Justiça até 31.12.2014”, mensurada em percentual, com o valor de 20\% em 2013 e 90\% em 2014.

Como inicialmente mencionado, não há uma similaridade tão intensa como do exemplo anterior, sendo possível observar que a própria ação do referido PPA não tem a mesma descrição do objetivo estratégico, concentrando-se a primeira essencialmente na realização de obras de infraestrutura, ao passo que, no planejamento estratégico, a infraestrutura não se limita à realização de obras, abrangendo também melhorias nas edificações, com a implantação de sinalização adequada e também os aspectos internos à infraestrutura, como o desenvolvimento de programas de ergonomia. Não havendo essa similaridade na descrição das próprias ações e objetivos, evidentemente não há como se exigir produtos, indicadores e metas equivalentes.

38 Consta previsão da meta de 333.213 unidades do produto “obras realizadas" para o período desse exercício financeiro, o que certamente deve-se a algum erro material, por não fazer sentido um número dessa magnitude. 
Mesmo assim, percebe-se a mesma dificuldade em se coordenar a ação dos agentes públicos envolvidos na gestão para que sigam um rumo claro, dada a pouca linearidade entre ambos os planejamentos, que não estabelecem indicações precisas do quê, como, quando e aonde se pretende chegar.

Também releva destacar a ação governamental do PPA SP 2012-2015 "Desenvolvimento de implementação de sistemas de informação", que tem como produto "unidades informatizadas", com a meta para o período de 2140 . No orçamento de 2013, esta ação, que tem o número 02.126.0303.4827, descrita como "desenvolvimento de programas, ampliação de sistemas, atualização de programas, renovação do parque de informática e infraestrutura lógica”, prevê serem informatizadas 535 unidades no respectivo exercício financeiro, com uma dotação de $\mathrm{R} \$ 213.769 .119,00$.

No planejamento estratégico 2010-2014, o objetivo 11 é "Aprimorar a informatização", descrito como "Entregar serviços de Tecnologia da Informação com a qualidade necessária, elevando o grau de percepção de valor agregado aos agentes públicos do TJSP e a satisfação dos usuários internos e externos, visando maior agilidade na tramitação dos processos judiciais e administrativos". Foram estabelecidas 15 (quinze) metas, a saber: implantar 70\% do Portal de Custas até 31.12.2014 (meta 1); implantar $100 \%$ do sistema de registro audiovisual de audiências nas Varas Criminais Centrais e Varas do Júri da Capital até 31.12.2014 (meta 2); implantar 100\% das soluções de Business Intelligence até 30.6.2013 (meta 3); implan$\operatorname{tar} 100 \%$ do Sistema único informatizado de gerenciamento de processos até 31.12.2013 (meta 4); ampliar o número de Varas Digitais para 40\% do total até 31.12.2013 (meta 5); implantar o controle digital de processos administrativos em todas as Secretarias diretamente relacionadas com a Presidência do TJSP e Corregedoria Geral de Justiça até 31.12.2013 (meta 6); implantar o controle digital de processos administrativos nas DARAJ (Departamento de Administração das Regiōes Administrativas) até 31.12.2014 (meta 7); implantar o controle digital de processos administrativos nas demais unidades da Administração até 31.12.2014 (meta 8); implantar 90\% do sistema informatizado de controle de precatórios até 31.12.2014 (meta 9); ajustar e implantar 100\% dos módulos do SAJADM da Secretaria de Orçamento e Finanças (SOF) até 31.12.2014 (meta 10); informatizar $100 \%$ da Secretaria de Planejamento de Recursos Humanos (SPRH) até 31.12.2014 (meta 11); informatizar 80\% da Secretaria de Gerenciamento de Recursos Humanos (SGRH) até 31.12.2014 (meta 12); informatizar 100\% da Secretaria da Área da Saúde (SAS) até 31.12.2014 (meta 13); criar e instalar processo digital em 100\% das Câmaras até 30.6.2014 (meta 14); e 100\% (percentual de implantação do projeto de importação dos dados de atuação de primeiro para segundo grau, projeto da Secretaria Judiciária). 
Nesse caso, veem-se claramente algumas das dificuldades de coordenação decorrentes da não afinidade entre os sistemas de planejamento. A ação governamental do PPA 2012-2015 prevê a informatização de 535 unidades em 2013 e 2.140 até o final de 2015, mas não deixa claro exatamente no que consiste "informatizar uma unidade”. Já o planejamento estratégico fala em "aprimorar a informatização" até o final de 2014, também não deixando claro o que se pretende exatamente com o objetivo descrito, que se desdobra em 15 metas, cada uma com previsões bastante diversas, como se pode ver, tendo descrições como "implantação de portal de custas", "implantação de sistemas de registro audiovisual em Varas Criminais", "implantar controle digital de processos administrativos", "implantar sistema informatizado de controle de precatórios" etc., todas correspondendo a descrições que podem ser consideradas "informatizações" de unidades. Note-se ainda que o planejamento estratégico, nas 15 metas, prevê na meta 5 "ampliar o número de Varas Digitais para $40 \%$ do total até 31.12.2013" e na meta 14 "criar e instalar processo digital em 100\% das Câmaras até 30.6.2014”; no PPA SP 2012-2015, encontramos a ação "Instalação de Varas e Câmaras Digitais", cujo produto são "unidades digitais" e a meta, para o período, de 1.515 unidades. No orçamento de 2013, a ação “instalação de varas e câmaras digitais" (número 02.061.0303.4828), descrita como "celeridade nos serviços judiciais prestados aos cidadãos, de sorte a atender aos anseios da sociedade", prevê a meta de 396 unidades do produto "unidades digitais" para o respectivo exercício financeiro, ao custo de $\mathrm{R} \$ 101.750 .280,00$. Embora, neste último exemplo, possa haver coerência entre as ações e os objetivos, pois em ambos há a previsão de digitalização de unidades, de primeira e segunda instâncias (varas e câmaras, respectivamente), as divergências entre os prazos e os dados deixam dúvidas sobre as metas, os produtos e os períodos em que devem ser atingidos. E, considerando haver, nessa hipótese, uma equivalência significativa entre ações, objetivos, produtos e metas, essas divergências levam à já anunciada insegurança dentro da administração sobre como agir de forma coesa, ressaltando-se, nesse caso, a multiplicidade de órgãos internos envolvidos, como as secretarias responsáveis por informática, recursos humanos, gerenciamento de primeira e segunda instância, todas organizaçôes internas que precisam de perfeita sintonia para atuar de modo a atingir os resultados pretendidos, o que será sobremaneira dificultado em caso de imprecisão na descrição de ações e prazos.

Não difere muito a situação se verificarmos situações mais recentes. No PPA SP 2016-2019, para utilizarmos um exemplo, o setor de tecnologia da informação está contemplado no Programa 0303, Produto "Unidades atendidas pelos sistemas de informação", tendo como indicadores "unidades administrativas e judiciais informatizadas (unidade)", cuja meta ao final do PPA é 2.140. Na lei orçamentária 
de 2016, o mesmo setor consta do Programa 0303, na ação "Desenvolvimento, implementação e manutenção de sistemas de informação (02.126.0303.4827)", descrita como "desenvolvimento de programas, ampliação de sistemas, atualização de programas, manutenção e renovação do parque de informática e infraestrutura lógica", cujo produto corresponde a "unidades atendidas pelos sistemas de informação", tendo como indicadores "unidades administrativas e judiciais informatizadas (unidade)", sendo previstas 533, ao qual foi destinado o montante de R\$ 415.036.129,00. No planejamento estratégico 2015-2020, o setor é contemplado no tema "Infraestrutura e tecnologia", em quatro objetivos estratégicos: a) objetivo estratégico 6, "expandir e aprimorar os recursos de TIC", que prevê sete metas; b) objetivo estratégico 7, "aprimorar a governança de TIC", com três metas; c) objetivo estratégico 8, "integrar os sistemas informatizados do TJSP com órgãos de governo e unidades extrajudiciais", com uma meta; e d) objetivo estratégico 9, "adequar infraestrutura física", com uma meta. E no tema "Eficiência dos serviços", no objetivo estratégico 16, "aprimorar e integrar os sistemas informatizados da SGRH”, com duas metas. No planejamento estratégico ora referido, à semelhança dos demais, não há a referência a valores financeiros correspondentes.

As mesmas observações e reparos, com as devidas adaptações, feitas anteriormente no que se refere às normas de planejamento precedentes, continuam presentes e aplicáveis, evidenciando que a multiplicidade documental elaborada com metodologias e propósitos distintos não permite uma perfeita sintonia entre elas, dificultando uma adequação do planejamento estratégico com as normas de planejamento orçamentário, até mesmo pela falta de um elemento essencial ao planejamento orçamentário, que são os recursos necessários, usualmente não fixados pelos demais documentos de planejamento.

O fato, em face dos exemplos mencionados, é que essa duplicidade de métodos e sistemas de planejamento simultâneos no âmbito do Poder Judiciário remete à análise de outros aspectos que merecem reflexão.

\subsection{COMPATIBILIZAÇÃO DO PLANEJAMENTO ORÇAMENTÁRIO DOS TRIBUNAIS COM O PLANEJAMENTO DO PODER JUDICIÁRIO EM ÂMBITO NACIONAL E ASPECTOS FEDERATIVOS}

Um dos aspectos que exigem análise e interpretação refere-se à coordenação entre o sistema de planejamento orçamentário governamental brasileiro, fundado na tríade de leis de natureza orçamentária do PPA-LDO-LOA em cada unidade da federação, com o planejamento do Poder Judiciário em âmbito nacional. 
Os tribunais sujeitam-se às determinações do Conselho Nacional de Justiça, a quem compete controlar a atuação administrativa e financeira do Poder Judiciário, órgão com competência nacional que instituiu a obrigatoriedade do planejamento estratégico para todos os tribunais do país, a serem elaborados "alinhados ao Plano Estratégico Nacional”. Há, portanto, diretrizes de caráter nacional, válidas para o Poder Judiciário de todo o país, às quais ficam submetidos os planejamentos estratégicos de todos os tribunais que compõem o Poder Judiciário. ${ }^{39}$

Considerando a organização do Poder Judiciário nacional, estruturada em tribunais que integram a administração pública federal, dos Estados e do Distrito Federal, constata-se que deverão os tribunais elaborar os respectivos planejamentos estratégicos seguindo as diretrizes em âmbito nacional fixadas pelo Conselho Nacional de Justiça, de forma a manter uma unidade de propósitos para todo o Poder Judiciário. O que se mostra, de fato, necessário, dada a unidade do Poder Judiciário, visível em vários aspectos. As cortes superiores, por exemplo, julgam em grau de recurso os processos oriundos dos tribunais das várias esferas da federação. Mesmo no âmbito estadual, há casos como o da competência delegada pela Justiça Federal às Justiças dos Estados, por exemplo, nas açōes previdenciárias, em que a Justiça Estadual realiza o julgamento em primeira instância, sendo os recursos das sentenças interpostos no tribunal competente da Justiça Federal. A falta de uniformidade de procedimentos prejudica em muito o funcionamento do sistema. É o que se pode constatar, a título exemplificativo, com a informatização, que, se não integrar um sistema uniforme em todo o país, seguido pelos tribunais das várias esferas de governo, inviabilizará a tramitação dos processos entre as várias cortes, da mesma ou diferentes instâncias. ${ }^{40}$ Essa questão foi observada por ocasião da análise feita pelo Tribunal de Contas da União, em seu Relatório Sistêmico sobre a Função Judiciária (FiscJudiciário), quando constatou que a autonomia administrativa e financeira dos tribunais fez com que cada um passasse a desenvolver sua própria versão de processo eletrônico, gerando preocupação com a compatibilidade dos diversos sistemas. Isso motivou a edição de normas por parte do Conselho Nacional de Justiça, como a Resolução n. 90/2009, visando à padronização e à acessibilidade dos sistemas, que avançou significativamente com a implantação do

\footnotetext{
39 Exceto o STF.
}

40 Cumpre observar que a área de informática do Poder Judiciário, dadas sua importância e complexidade, deve ter um planejamento estratégico próprio, conforme determina a Resolução CNJ n. 99, de 24 de janeiro de 2009 ("Institui o Planejamento Estratégico de Tecnologia da Informação e Comunicação no âmbito do Poder Judiciário”), sucedida pela Resolução n. 211, de 15 de dezembro de 2015 ("Institui a Estratégia Nacional de Tecnologia da Informação e Comunicação do Poder Judiciário - ENTIC-JUD”). 
Processo Judicial Eletrônico (PJe), que se tornou padrão para toda a justiça federal. ${ }^{41}$ Há que se considerar ainda a sempre presente e necessária relação entre os tribunais, causadas por diversos fatores, tal como o cumprimento de determinaçôes de um tribunal por outro, como é o caso de oitiva de testemunhas por cartas precatórias, execuções de sentenças e decisões, diligências judiciais diversas de que os tribunais necessitam com a cooperação dos demais para se efetivar e tantos outros. Não haverá como tornar viável o funcionamento do Poder Judiciário, em face principalmente do uso que se intensifica das cada vez mais modernas tecnologias, sem que todos estejam alinhados com esses procedimentos e sistemas.

Imprescindível, portanto, um planejamento do Poder Judiciário em nível nacional, que coordene e estabeleça diretrizes para todos os tribunais, independentemente do ente da federação a que pertençam.

No entanto, a organização federativa pressupõe respeito à autonomia dos entes federados, e o sistema de planejamento orçamentário governamental faz-se no âmbito de cada unidade da federação.

O orçamento de um tribunal estadual, como é o caso de São Paulo, por exemplo, é parte integrante do orçamento do Estado de São Paulo, e o mesmo ocorre com as demais leis que formam o sistema de planejamento orçamentário governamental - caso do PPA, da LDO e da LOA. São todas leis elaboradas para o ente federado, do qual o Poder Judiciário é parte integrante, como já se ressaltou.

O planejamento orçamentário do Poder Judiciário materializado em sua participaçãao no PPA do respectivo ente da federação terá de guardar relação de coerência com o planejamento estratégico do referido tribunal, que, por sua vez, está necessariamente alinhado às diretrizes nacionais do Poder Judiciário.

Evidentemente, não é tarefa simples estabelecer um sistema de planejamento orçamentário para um tribunal - especialmente estadual ou distrital - que consiga, ao mesmo tempo, alinhar-se a um planejamento nacional do Poder Judiciário e a um planejamento do ente da federação a que pertence, sem a ocorrência de conflitos.

No caso específico do Poder Judiciário, há elementos que facilitam esse ajuste e possibilitam a construção do sistema com coesão e lógica.

O Poder Judiciário é dotado de autonomia financeira e administrativa, por expressas disposições constitucionais, competindo-lhe apresentar sua proposta orçamentária, nos limites estipulados conjuntamente com os demais poderes na Lei

41 BRASIL. Tribunal de Contas da União. Acórdão 1.295/2015 - TCU - Plenário, Rel. Min. José Múcio Monteiro, sessão de 27.5.2015, p. 21. 
de Diretrizes Orçamentárias (Constituição, art. 99, $\$ 1^{\circ}$ ). Tem, por conseguinte, ampla liberdade para construir seu orçamento, estipulando os programas e seus componentes (objetivos, resultados, metas etc.), os órgãos internos e as dotações correspondentes. Com isso, torna-se mais simples adequar seu orçamento ao planejamento estratégico de forma compatível com as diretrizes do Plano Estratégico Nacional.

Convém observar que a Constituição brasileira assegura aos tribunais a iniciativa da proposta orçamentária, o que, à primeira vista, parece indicar que o dispositivo se aplica tão somente às propostas de orçamento dos tribunais que serão incorporadas nas leis orçamentárias anuais. Nenhuma referência faz ao Plano Plurianual, principal instrumento de planejamento orçamentário governamental de médio prazo.

No entanto, a análise sistemática do texto constitucional leva inexoravelmente à conclusão de que os tribunais também gozam da prerrogativa de apresentar as respectivas propostas de Plano Plurianual a serem incorporadas aos projetos de Plano Plurianual apresentados pelo Poder Executivo nas datas fixadas.

Esse entendimento segue na esteira de que o Poder Judiciário tem iniciativa legislativa "em toda e qualquer matéria financeira que seja diretamente relacionada a seus interesses", como abertura de créditos adicionais, criação de fundos ou alteração da legislação sobre temas dessa natureza, como já houve oportunidade de expor em outro texto. ${ }^{42}$

No Plano Plurianual, como se tem defendido ao longo do trabalho, fixam-se as diretrizes, os objetivos e as metas da administração pública no médio prazo, que parametrizarão as leis de diretrizes orçamentárias e leis orçamentárias anuais no período. A autonomia financeira que a Constituição assegurou ao Poder Judiciário, por vários instrumentos, dos quais o principal é a iniciativa de sua proposta orçamentária, ficará de todo prejudicada caso essa prerrogativa não se estenda ao Plano Plurianual.

Não se coaduna com a independência de poderes assegurada pelo art. $2^{\circ} \mathrm{da}$ Constituição, que configura cláusula pétrea (Constituição, art. $60, \$ 4^{\circ}$, III), tendo na autonomia financeira do Poder Judiciário ${ }^{43}$ um dos pilares que a sustenta, permitir que o Poder Executivo exerça a iniciativa em matéria de Plano Plurianual de forma abrangente, incluindo a parte relativa ao Poder Judiciário, de modo a estabelecer as diretrizes, os objetivos e as metas desse poder para o quadriênio seguinte.

42 CONTI, José Mauricio. Autonomia financeira do Poder Judiciário, p. 92.

43 E demais instituiçôes independentes, como o Ministério Público e a Defensoria Pública. 
Nesse caso, a autonomia financeira do Poder Judiciário assegurada pelo art. 99, $\$$ $1^{\circ}$, limitar-se-ia a elaborar sua proposta orçamentária, que estaria condicionada pelo Plano Plurianual elaborado e apresentado pelo Poder Executivo, sem sua interferência, mitigando de forma substancial os propósitos do texto constitucional.

É oportuno lembrar que a sistemática atualmente adotada para o sistema de planejamento orçamentário da administração pública prevê a definição da estrutura programática no Plano Plurianual, que condicionará a elaboração da Lei Orçamentária Anual, devendo esta ser com ele coerente, como já exposto anteriormente.

Fato que, em regra, como se observa no orçamento federal, e também nos orçamentos estaduais, a estrutura programática tem estabelecido um único programa para cada unidade orçamentária no âmbito do Poder Judiciário, o que é bastante favorável em termos de respeito à autonomia financeira do Poder, por permitir maior margem de liberdade no gerenciamento dos recursos e mesmo na definição dos elementos que compóem o programa, como na especificação das ações governamentais. De qualquer forma, isso não altera a prerrogativa que deve ser respeitada de participação do Poder Judiciário na iniciativa legislativa do PPA, mesmo porque, como se pode observar, os programas que compõem o PPA vêm desdobrados nas ações governamentais que o integram, e a descrição das ações governamentais é fundamental na definição dos rumos a se adotar pelo planejamento do Poder Judiciário, e terá de guardar compatibilidade, coerência e coordenação com o planejamento estratégico que caberá ao Poder Judiciário elaborar e adotar, dessa feita sem a participação de quaisquer outros Poderes.

Sendo assim, não só mitigada, mas inequivocamente violada, a autonomia financeira do Poder Judiciário se, por ocasião da elaboração do PPA, não lhe for outorgada a prerrogativa de elaboração da parte que lhe couber na formação da estrutura programática do PPA.

Não há, portanto, outra interpretação possível para o texto constitucional que compatibilize a autonomia financeira constitucional do Poder Judiciário com o sistema de planejamento orçamentário governamental que não reconheça a este poder o direito de participação na elaboração do Plano Plurianual. A coerência e a lógica do sistema só se perfazem com o reconhecimento de que o Poder Judiciário também tem iniciativa privativa na elaboração da parte que lhe cabe na proposta de Plano Plurianual. Só assim é possível dar coesão às normas de planejamento orçamentário que exigem a observância, pelos tribunais, ao elaborarem suas propostas orçamentárias, do respeito tanto ao plano plurianual vigente quanto ao disposto no art. 4º da Resolução CNJ n. 198, que determina a previsão dos recursos necessários para cumprir o disposto nos respectivos planejamentos estratégicos. 
Sendo assim, os tribunais não terão significativos empecilhos para que seu planejamento orçamentário de médio prazo seja compatível tanto com o Plano Plurianual do ente federado quanto do planejamento estratégico nacional.

\subsection{DESCONEXÃO TEMPORAL | NÃO COINCIDÊNCIA DE PRAZOS DAS NORMAS DE PLANEJAMENTO}

Outra questão que exige reflexão, em face da dificuldade na compatibilização e na consequente interpretação das normas de planejamento envolvidas, refere-se à divergência quanto aos prazos de vigência.

O exemplo do Poder Judiciário mostra-se adequado para ilustrar e expor a questão, tendo em vista a regulamentação já existente sobre o tema no âmbito deste Poder, e estarem todos os tribunais com os planejamentos de natureza plurianual implantados, o que permite uma análise mais concreta e diversificada.

Os planos plurianuais dos entes da federação brasileira, pela legislação atualmente vigente, são quadrienais, e os planejamentos estratégicos dos tribunais abrangem um prazo mínimo de cinco anos (conforme determinação vigente do Conselho Nacional de Justiça de 2009 - Resolução n. 70), e seis anos, a partir de 2015 (Resolução n. 198, de 2014), o que permite concluir que não serão integralmente coincidentes.

Em razão disso, haverá períodos em que o PPA quadrienal do ente federado finda seu prazo de vigência, com o planejamento estratégico de cinco ou seis anos do Poder Judiciário dele integrante ainda em vigor; outras vezes, o planejamento estratégico chega a seu prazo final estando o PPA vigente. Em ambas as hipóteses, o novo planejamento, quer seja materializado no PPA, quer no planejamento estratégico, terá de ser renovado de forma coerente com o que estiver em vigor, exigindo uma interpretação que permita compatibilizar ambos os instrumentos jurídicos de planejamento de modo a formar um sistema de planejamento governamental coeso e seguro.

Considerando ser o PPA veiculado por lei, tem prevalência sobre o planejamento estratégico do Poder Judiciário, materializado em normas editadas no âmbito do órgão. Por vezes, findar-se-á o prazo de vigência do PPA, estando ainda em vigor o planejamento estratégico, o que pode gerar dúvidas sobre a permanência da vigência do planejamento estratégico, tendo em vista que haverá a renovação do PPA, que sobre ele prevalece.

É o que ocorreu no âmbito do Estado de São Paulo, apenas para exemplificar, com o PPA 2012-2015 e o planejamento estratégico do Tribunal de Justiça para o período 2010-2014. Em julho de 2015 (e, portanto, com atraso de sete meses), 
entrou em vigor o planejamento estratégico para o período de 2015 a 2020 (Resolução n. 706, de 31 de julho de 2015). Nesse caso, ao final de 2014, o planejamento estratégico exauriu sua vigência, estando em vigor o PPA, que só findou em 2015. Portanto, nenhuma dúvida resta quanto à necessidade de o planejamento estratégico observar o PPA, pelo menos no período do exercício financeiro de 2015. No entanto, o novo planejamento estratégico do Poder Judiciário paulista estabelece as diretrizes e metas para o período de 2015 a 2020, enquanto o PPA do Estado de São Paulo vigora para o período de 2016 a 2019. Sendo assim, no ano de 2020, a situação se inverte. No exercício de 2020, o PPA terá exaurido sua vigência, estando em vigor o planejamento estratégico. Havendo prevalência do PPA sobre o planejamento estratégico, não é exigível que a elaboração do novo PPA fique condicionada ao planejamento estratégico em vigor. Contudo, haverá grande insegurança jurídica no planejamento estratégico 2015-2020 se, desde logo, sabe-se que em pouco tempo surgirá um PPA que poderá sobrepor-se a ele, e eventualmente alterar o planejamento, o que prejudicará sobremaneira a eficácia da referida norma.

Nessa hipótese, a solução que se mostra coerente com o ordenamento e com a dinâmica do planejamento passa pela já discutida autonomia financeira do Poder Judiciário em matéria orçamentária, que, como concluímos, confere ao Poder Judiciário a prerrogativa de elaborar a parte que lhe cabe no PPA. Tendo o Poder Judiciário a iniciativa de apresentar sua proposta de planejamento plurianual para inserção no PPA, há que se concluir estar ele, nessa tarefa, vinculado a fazê-lo de forma compatível com o planejamento estratégico vigente. Sendo assim, torna-se inviável a inserção no PPA de proposta não compatível com o planejamento estratégico. ${ }^{44}$ Com isso, mantêm-se a coerência do sistema de planejamento e a segurança jurídica das normas que o veiculam.

\subsection{DIFERENTES COMPETÊNCIAS ENTRE PPA E PLANEJAMENTO ESTRATÉGICO}

A função do Planejamento Estratégico (PE) é essencialmente administrativa, um plano de gestão, não necessariamente orçamentário, que segue os princípios e conceitos de administração pública, ${ }^{45}$ razão pela qual, embora deva existir uma

44 Eventual incompatibilidade surgiria tão somente em caso de alteração decorrente de emenda parlamentar na fase legislativa de elaboração do PPA, caso em que, sendo aprovada a lei, evidentemente o planejamento estratégico terá de se adaptar.

45 De certa forma, e em boa medida, com base em conceitos e técnicas de administração próprias do setor privado, em face das metodologias adotadas. 
perfeita coordenação entre o PE e o PPA, tratam de temas que não são necessárias nem inteiramente coincidentes, ainda que tenham muitos pontos de conexão e inter-relação.

No entanto, embora se tenha adotado para o Poder Judiciário a institucionalização do planejamento estratégico, cujas características delineadas pela Resolução n. 70/2009 mostram ser ele um instrumento de gestão, com forte conotação de princípios da administração do setor privado, acolhendo e adotando conceitos próprios das empresas privadas, isso não significa que tenha sido esta a melhor opção.

O planejamento estratégico "consiste em antecipar racionalmente as ações visando a atingir determinados objetivos do modo mais econômico possível. Significa, em suma, prever os distintos cenários que o futuro pode materializar, identificando, em tempo hábil, eventuais ameaças ou possíveis oportunidades"; deve-se "conceber um objetivo e coordenar todas as açôes para atingi-lo, integrando-as em um conjunto único. As ações singulares, intermediárias, periféricas e circunstanciais, enfim, todas as açôes, qualquer que sejam elas, devem subordinar-se a um fim último colimado, evitando-se a dispersão de esforços". ${ }^{46}$

Vê-se estar mais focado nos aspectos gerenciais do Poder Judiciário, no qual as questôes orçamentárias são instrumentais, e com maior ou menor relevância em função das características dos objetivos estabelecidos.

No entanto, como se pode notar, embora instrumentais, e aplicáveis com maior intensidade em boa parte - e não seria exagero dizer, na maior parte - das ações governamentais que levarão ao atingimento dos objetivos, a questão orçamentária ocupa papel central no âmbito do planejamento.

Como se argumentou no início, não faz sentido termos - corretamente, ressalte-se -, a exigência de um sistema de planejamento orçamentário governamental fundado no "tripé normativo" PPA-LDO-LOA para todos os entes da Federação, o que abrange desde a União, cujo orçamento anual prevê receitas de $\mathrm{R} \$$ 3.565.520.100.068,00 (orçamento da União para 2020), até os menores municípios, como Borá (SP), com população aproximada de 836 habitantes e receita líquida anual prevista para 2020 inferior a 20 milhões de reais ${ }^{47}$ - e que fica, portanto, no patamar de milhões de reais -, e não exigir o mesmo para o Tribunal de Justiça do Estado de São Paulo, com mais de 45 mil servidores e orçamento de despesas previsto em R \$ 12.309.176.640,00 (dados do orçamento do Estado de São Paulo de 2020 - Lei estadual 17.244/2020), que sobe para o nível de bilhões de reais.

46 LEWANDOWSKI, Enrique R. Planejamento estratégico do Poder Judiciário, p. 17-18.

47 Disponível em: <www.bora.sp.gov.br>. Acesso em: 11 out. 2016. 
Sendo assim, vê-se ser imprescindível que se institua, para órgãos de grandes dimensões, um sistema de planejamento orçamentário governamental nos mesmos moldes do que se estabelece para os entes da federação, sem o que não se poderá construir um sistema eficiente de planejamento, gestão e, também, controle dos gastos públicos. A instituição de um sistema como o determinado e estruturado pelo CNJ, na forma de planejamento estratégico, é sem dúvida um grande avanço, mas não se mostra suficiente para suprir a necessidade de um detalhamento orçamentário como o previsto para os entes da federação.

E o PPA não tem sido um instrumento adequado e suficiente para formalizar o planejamento orçamentário do Poder Judiciário, uma vez que, como já ressaltado, até mesmo para que permita uma maior flexibilidade na alocação de recursos e consequente respeito à autonomia financeira do Poder Judiciário, tem estabelecido um único programa para cada unidade orçamentária em que se desdobram os órgãos que compõem o Poder Judiciário. Com isso, há pouco detalhamento, e, mesmo com o desdobramento do programa em ações, estas ainda se mostram bastante genéricas, e por vezes até mesmo pouco representativas dos objetivos, resultados e metas a serem idealmente perseguidos, prejudicando o uso desse instrumento normativo como efetivo condutor dos rumos da instituição.

Além disso, os planos plurianuais não têm forma e metodologia formalmente estabelecidos, uma vez que não há legislação complementar regulamentando-os, pois foram criados na Constituição de 1988, sendo, por conseguinte, posteriores à Lei n. 4.320/1964; e a Lei de Responsabilidade Fiscal, de 2000, foi omissa a respeito, tendo sido vetado o único artigo que lhes fazia referência (art. $3^{\circ}$ ). Os planos plurianuais, a despeito de críticas, como já abordado em capítulos anteriores, têm mantido o viés orçamentário, mas a metodologia, as técnicas e a linguagem sofrem alterações a cada nova edição, o que pode ser observado com clareza na esfera federal, e nota-se também no âmbito dos estados e municípios; nestes últimos, inclusive, especialmente nos de menor dimensão, têm tido pouca representatividade em termos de instrumento de planejamento. ${ }^{48}$ Sendo assim, além da diferença temporal entre os planos plurianuais, o que já é uma razão que prejudica sua elaboração, execução e acompanhamento, há ainda que se conviver com a diferença espacial, pois a falta de norma geral permite que cada ente da federação adote metodologias

\footnotetext{
48 "Planos plurianuais municipais, especialmente de municípios menores, são elaborados com base em modelos que se repetem ano a ano, sem uma efetiva preocupação dos prefeitos nele incorporarem as previsões para o que se vai fazer no decorrer do mandato", como escrito em texto de minha autoria (Planejamento municipal precisa ser levado a sério. Levando o direito financeiro a sério, p. 135-138).
} 
distintas, dificultando ainda mais a coordenação entre os planos, o que, no mais das vezes, é imprescindível para a viabilização de inúmeras políticas públicas de natureza transversal e interfederativa.

Eventual intervenção do Conselho Nacional de Justiça nessa área não terá condiçōes de apresentar soluções satisfatórias para orientar com precisão esse planejamento orçamentário do Poder Judiciário na falta de uma norma geral regulamentadora, uma vez que não terá como se compatibilizar com as características próprias do planejamento orçamentário de cada ente da federação.

Torna-se uma tarefa de dificuldade quase intransponível, na falta de uma norma geral que estabeleça parâmetros uniformes para o planejamento orçamentário da administração pública, a compatibilização de um planejamento orçamentário do Poder Judiciário com o planejamento orçamentário do próprio ente a que pertence, especialmente se não tiverem prazos coincidentes, bem como a coordenação necessária entre o planejamento nacional de caráter estratégico do Poder Judiciário com o planejamento orçamentário de cada órgão do Poder Judiciário dos vários entes da federação.

\subsection{PODER JUDICIÁRIO, CONTROLE JUDICIAL E A INTERFERÊNCIA NO PLANEJAMENTO ORÇAMENTÁRIO DA ADMINISTRAÇÃO PÚBLICA}

Como visto até o momento neste capítulo, o Poder Judiciário, como órgão da Administração Pública, apresenta várias dificuldades, ainda que superáveis, para se inserir no sistema de planejamento orçamentário, de modo que seja possível com ele compatibilizar-se e integrar um sistema coeso, que permita ver respeitada sua autonomia ao mesmo tempo que se coordene com os demais órgãos de forma harmônica e com unidade de propósitos.

Outra questão que tem se tornado de elevada relevância em matéria de planejamento orçamentário diretamente ligada ao Poder Judiciário refere-se à sua atuação no exercício de sua função institucional como Poder de Estado.

Ao julgar as questóes e dirimir as controvérsias, o Poder Judiciário tem interferido cada vez mais no orçamento público, proferindo decisões que determinam a realização de gastos ou a imposição de obrigaçóes que exigem dispêndio de recursos públicos para serem cumpridas. Uma interferência que tem se intensificado cada vez mais, e não pode mais ser desconsiderada por todo o sistema de planejamento orçamentário da administração pública.

Tornou-se necessário que o planejamento orçamentário abranja esse novo fato jurídico e econômico que se tornou relevante no âmbito das despesas públicas, não 
sendo mais possível considerá-lo um gasto imprevisível em sua integralidade, dada a regularidade com que se tem constatada sua ocorrência.

Não se pretende neste trabalho entrar na tormentosa e controvertida questão da interferência do Poder Judiciário em matéria orçamentária em sua fase de execução, mas não se pode deixar de analisar decisões mais recentes, cuja intensidade é crescente, que tem implicado diretamente, de formas diversas, no planejamento orçamentário.

Decisões do Poder Judiciário que impõem obrigações no âmbito do sistema de planejamento orçamentário, e que, portanto, de forma diversa das anteriormente mencionadas, não atuam na fase de execução orçamentária, determinando a realocação das despesas, mas sim em momento precedente, na fase de elaboração orçamentária nas normas que integram o sistema de planejamento orçamentário e precedem a própria elaboração da lei orçamentária, ou, ainda, exigindo o cumprimento das leis de planejamento orçamentário.

Está-se diante do que podemos denominar judicialização do planejamento orçamentário.

Judicialização essa que se manifesta de diversas formas, que podemos classificar em dois grandes grupos: o que precede a elaboração das normas de planejamento; e os casos de judicialização na fase de execução das normas de planejamento.

No primeiro grupo, encontramos, entre outros, os casos de judicialização em que se pretende obrigar o Estado a exercer sua função planejadora, elaborando planos que viabilizem a implementação de políticas públicas e deem cumprimento a determinações constitucionais e legais, concretizando direitos. Há, também, casos em que se busca a interferência no planejamento com a inclusão nos instrumentos de planejamento orçamentário de ações, objetivos e/ou metas. Hipóteses em que se colocam em discussão os limites da separação de poderes e o sistema democrático de elaboração da lei orçamentária, baseada na atuação dos poderes Executivo e Legislativo, responsáveis pela elaboração das leis de planejamento orçamentário, que devem refletir nelas as decisões da sociedade acerca da alocação dos recursos públicos para o exercício financeiro. Pode resultar em medidas do Poder Judiciário que determinem a alocação dos recursos, condicionando a própria elaboração da lei orçamentária e, por conseguinte, balizando e limitando a atuação dos demais Poderes, a quem cabem a iniciativa e a aprovação da lei orçamentária.

No segundo grupo, encontram-se casos de judicialização que têm por finalidade exigir o cumprimento dos planos aprovados. Há planos materializados em instrumentos jurídicos, fazendo-se uso da via judicial para obrigar o Poder Público a lhe dar plena eficácia. 
Não será analisada a questão sob o prisma da lei orçamentária, embora essa seja um instrumento de planejamento orçamentário de curto prazo, uma vez que se estaria no âmbito da discussão da natureza da lei orçamentária propriamente dita, e o que se pretende, neste momento, é avançar nas questões voltadas mais diretamente ao sistema de planejamento orçamentário, razão pela qual o enfoque dar-se-á aos instrumentos de médio e longo prazo.

Alguns casos recentes são paradigmáticos, valendo destacá-los para, a partir deles, desenvolver a análise e, com isso, ilustrar e melhor compreender esta que é uma questão ainda recente no âmbito do planejamento orçamentário.

\subsubsection{O Poder Judiciário e a judicialização do planejamento na fase de elaboração}

Um exemplo recente, inovador e polêmico, a partir do qual se pode analisar a interferência do Poder Judiciário no planejamento governamental, pode ser extraído da Arguição de Descumprimento de Preceito Fundamental (ADPF) n. 347, iniciada em maio de 2015, movida pelo Partido do Socialismo e Liberdade (PSOL) contra a União, tendo por objeto a situação carcerária do país.

$\mathrm{Na}$ petição inicial, os argumentos aduzidos pelo PSOL sustentaram a tese de que haveria um estado de coisas inconstitucional no sistema penitenciário brasileiro e, por essa razão, pede a adoção de medidas de saneamento de lesões a preceitos fundamentais da Constituição. A busca de intervenção judicial diante de problemas estruturais nas políticas públicas destinadas a assegurar direitos fundamentais teve inspiração direta em decisões da Corte Constitucional colombiana, defendendo-se a conformidade com o sistema constitucional brasileiro. Em situações caracterizadas como excepcionais afrontas aos direitos humanos, haveria, da parte do órgão de controle de constitucionalidade, o amplo poder de determinar a suspensão de um "bloqueio institucional" à garantia dos direitos, o que mitigaria concepção mais estrita da separação de poderes para dar lugar a possibilidades mais amplas de intervenção em políticas públicas. Diante disso, como a concretização de que alguns direitos dependem da prestação estatal - e, por conseguinte, do orçamento público -, justificar-se-ia a tutela jurisdicional para cessar o estado de coisas inconstitucional, ainda que isso implique a determinação de adaptações no planejamento governamental. Aduzem estar presentes as situações que permitem caracterizar a excepcionalidade na afronta aos direitos humanos em face das péssimas condições do sistema penitenciário, decorrente de prolongada omissão das autoridades, exigindo que sejam tomadas medidas estruturais complexas por uma pluralidade de órgãos. E a ADPF se prestaria como meio adequado de atuação do Supremo 
Tribunal Federal em políticas públicas, pois, na forma como é disciplinada pelo art. 102 da Constituição Federal e pela Lei n. 9.882/1999, volta-se a situações em que haja lesão ou ameaça a preceito fundamental causada por atos do Poder Público, não havendo outro instrumento apto a saná-las.

Entre os vários pedidos formulados, destaca-se, para os fins do que ora se discute, o que pede que se determine "ao Governo Federal que elabore e encaminhe ao STF, no prazo máximo de 3 meses, um plano nacional ('Plano Nacional') visando à superação do estado de coisas inconstitucional do sistema penitenciário brasileiro, dentro de um prazo de 3 anos", seguido dos pedidos complementares detalhando vários aspectos do referido plano. ${ }^{49}$

49 O pedido formulado, no que tange ao plano, é detalhado, como se pode constatar da reprodução da íntegra na parte que dele trata:

“c) Determinar ao Governo Federal que elabore e encaminhe ao STF, no prazo máximo de 3 meses, um plano nacional ("Plano Nacional") visando à superação do estado de coisas inconstitucional do sistema penitenciário brasileiro, dentro de um prazo de 3 anos.

O Plano Nacional deverá conter propostas e metas específicas para a superação das graves violações aos direitos fundamentais dos presos em todo o país, especialmente no que toca à (i) redução da superlotação dos presídios; (ii) contenção e reversão do processo de hiperencarceramento existente no país; (ii) diminuição do número de presos provisórios; (iii) adequação das instalações e alojamentos dos estabelecimentos prisionais aos parâmetros normativos vigentes, no que tange a aspectos como espaço mínimo, lotação máxima, salubridade e condições de higiene, conforto e segurança; (iv) efetiva separação dos detentos de acordo com critérios como sexo, idade, situação processual e natureza do delito; (v) garantia de assistência material, de segurança, de alimentação adequada, de acesso à justiça, à educação, à assistência médica integral e ao trabalho digno e remunerado para os presos; (vi) contratação e capacitação de pessoal para as instituiçôes prisionais; (vii) eliminação de tortura, de maus-tratos e de aplicação de penalidades sem o devido processo legal nos estabelecimentos prisionais; (viii) adoção de medidas visando a propiciar o tratamento adequado para grupos vulneráveis nas prisões, como mulheres e população LGBT.

O Plano Nacional deve conter, também, a previsão dos recursos necessários para a implementação das suas propostas, bem como a definição de um cronograma para a efetivação das medidas de incumbência da União Federal e de suas entidades.

d) Submeter o Plano Nacional à análise do Conselho Nacional de Justiça, da Procuradoria Geral da República, da Defensoria Geral da União, do Conselho Federal da Ordem dos Advogados do Brasil, do Conselho Nacional do Ministério Público, e de outros órgãos e instituiçôes que queiram se manifestar sobre o mesmo, além de ouvir a sociedade civil, por meio da realização de uma ou mais audiências públicas.

e) Deliberar sobre o Plano Nacional, para homologá-lo ou impor medidas alternativas ou complementares, que o STF reputar necessárias para a superação do estado de coisas inconstitucional. Nesta tarefa, a Corte pode se valer do auxílio do Departamento de Monitoramento e Fiscalização do Sistema Carcerário e do Sistema de Execução de Medidas Socioeducativas do Conselho Nacional de Justiça.

f) Após a deliberação sobre o Plano Nacional, determinar ao governo de cada Estado e do Distrito Federal que formule e apresente ao STF, no prazo de 3 meses, um plano estadual ou 
Não há decisão final de mérito a respeito, estando o caso em andamento, tendo sido apreciadas, até o momento, apenas as medidas cautelares pleiteadas, ${ }^{50}$ nas quais vários argumentos evidenciam temas importantes ligados à intervenção do Poder Judiciário em políticas públicas, que também se relacionam com o sistema de planejamento.

Um dos principais e mais controvertidos pontos de conflito na intervenção do Poder Judiciário em políticas públicas está na delicada delimitação das atribuições dos poderes, por se tratar de hipótese em que o Judiciário estaria invadindo a esfera de atuação dos demais.

O Ministro Marco Aurélio, em seu voto, rebate esse argumento, ao reconhecer que, embora a interferência em políticas públicas e escolhas orçamentárias seja função atípica e excepcional do Supremo Tribunal Federal, é admissível que tome parte nessas decisões quando se reconhece estarem presentes os pressupostos do estado de coisas inconstitucional, sem que isso importe em afronta ao princípio democrático e da separação de poderes. Segundo o Ministro, cabe ao Tribunal “o papel de retirar os demais Poderes da inércia, catalisar os debates e novas políticas

distrital, que se harmonize com o Plano Nacional homologado, e que contenha metas e propostas específicas para a superação do estado de coisas inconstitucional na respectiva unidade federativa, no prazo máximo de 2 anos. Cada plano estadual ou distrital deve tratar, no mínimo, de todos os aspectos referidos no item 'c' supra, e conter previsão dos recursos necessários para a implementação das suas propostas, bem como a definição de um cronograma para a efetivação das mesmas.

g) Submeter os planos estaduais e distrital à análise do Conselho Nacional de Justiça, da Procuradoria Geral da República, do Ministério Público da respectiva unidade federativa, da Defensoria Geral da União, da Defensoria Pública do ente federativo em questão, do Conselho Seccional da $\mathrm{OAB}$ da unidade federativa, e de outros órgãos e instituiçốes que queiram se manifestar. Submetê-los, ainda, à sociedade civil local, em audiências públicas a serem realizadas nas capitais dos respectivos entes federativos, podendo a Corte, para tanto, delegar a realização das diligências a juízes auxiliares, ou mesmo a magistrados da localidade, nos termos do art. 22, II, do Regimento Interno do STF.

h) Deliberar sobre cada plano estadual e distrital, para homologá-los ou impor outras medidas alternativas ou complementares que o STF reputar necessárias para a superação do estado de coisas inconstitucional na unidade federativa em questão. Nessa tarefa, mais uma vez, a Corte Suprema pode se valer do auxílio do Departamento de Monitoramento e Fiscalização do Sistema Carcerário e do Sistema de Execução de Medidas Socioeducativas do Conselho Nacional de Justiça. i) Monitorar a implementação do Plano Nacional e dos planos estaduais e distrital, com o auxílio do Departamento de Monitoramento e Fiscalização do Sistema Carcerário e do Sistema de Execução de Medidas Socioeducativas do Conselho Nacional de Justiça, em processo público e transparente, aberto à participação colaborativa da sociedade civil, até que se considere sanado o estado de coisas inconstitucional do sistema prisional brasileiro".

50 BRASIL. Supremo Tribunal Federal. ADPF 347 MC. Rel. Min. Marco Aurélio, j. 9.9.2015. 
públicas, coordenar as ações e monitorar os resultados", superando "os bloqueios políticos e institucionais que vêm impedindo o avanço de soluções". Nessas hipóteses, "a intervenção judicial mostra-se legítima presente padrão elevado de omissão estatal frente a situação de violação generalizada de direitos fundamentais". ${ }^{51} \mathrm{E}$ segue, afirmando que "a intervenção judicial é reclamada ante a incapacidade demonstrada pelas instituiçôes legislativas e administrativas", e a "intervenção judicial equilibrada, inclusive quando há envolvimento de escolhas orçamentárias, não pode ser indicada como fator de afronta às capacidades institucionais dos outros Poderes, se o exercício vem se revelando desastroso”. Desse modo,

"cabe ao Supremo catalisar açôes e políticas públicas, coordenar a atuação dos órgãos do Estado na adoção dessas medidas e monitorar a eficiência das soluçôes. Não lhe incumbe, no entanto, definir o conteúdo próprio dessas políticas, os detalhes dos meios a serem empregados. Em vez de desprezar as capacidades institucionais dos outros Poderes, deve coordená-las, a fim de afastar o estado de inércia e deficiência estatal permanente. Não se trata de substituição aos demais Poderes, e sim de oferecimento de incentivos, parâmetros e objetivos indispensáveis à atuação de cada qual, deixando-lhes o estabelecimento das minúcias".

Delineia dessa forma os limites do que seria a legítima atuação excepcional do Poder Judiciário nessas hipóteses, de modo a cumprir sua função constitucional sem avançar nas esferas de competência dos outros Poderes:

"Ao Supremo cumpre interferir nas escolhas orçamentárias e nos ciclos de formulação, implementação e avaliação de políticas públicas, mas sem detalhá-las. Deve formular ordens flexíveis, com margem de criação legislativa e de execução a serem esquematizadas e avançadas pelos outros Poderes, cabendo-lhe reter jurisdição para monitorar a observância da decisão e o sucesso dos meios escolhidos. Ao atuar assim, reservará aos Poderes Executivo e Legislativo o campo democrático e técnico de escolhas sobre a forma mais adequada para a superação do estado de inconstitucionalidades, vindo apenas a colocar a máquina estatal em movimento e cuidar da harmonia dessas açōes".

E conclui:

"Esse é, enfim, o papel que deve desempenhar o Tribunal em favor da superação do quadro de inconstitucionalidades do sistema prisional: retirar as autoridades públicas do estado de letargia, provocar a formulação de novas políticas públicas, aumentar a deliberação política e social sobre a matéria e monitorar o sucesso da implementação das providências escolhidas, assegurando, assim, a efetividade prática das soluçōes propostas". ${ }^{2}$

51 BRASIL. Supremo Tribunal Federal. ADPF 347 MC, Voto Min. Marco Aurélio.

52 BRASIL. Supremo Tribunal Federal. ADPF 347 MC, Voto Min. Marco Aurélio. 
Na mesma linha, segue o Ministro Edson Fachin, de cujo voto vale destacar argumentos complementares, como o de que, na hipótese em discussão, o STF não está sendo usado como um "espaço constituinte permanente, mas sim como um Poder que atua contramajoritariamente para a guarda da Constituição e a proteção de direitos fundamentais que vêm sendo sistematicamente violados pelos Poderes que lhes deveriam dar concretude", e não se pode invocar a separação de poderes e a política democrática para impedir a atuação do Poder Judiciário "diante da inércia intencional e sistemática dos demais Poderes, de quem deve guardar a Constituição", pois, "quando os direitos de minorias excluídas são sistematicamente violados, é o Poder Judiciário o último guardião desses direitos e o Supremo Tribunal Federal deve deles fazer sua morada". ${ }^{3}$

O Ministro Celso de Mello em seu voto chama a atenção no mesmo sentido, asseverando que

"Desse modo, e para que o regime democrático não se reduza a uma categoria político-jurídica meramente conceitual ou simplesmente formal, torna-se necessário assegurar, às minorias e aos grupos vulneráveis, notadamente em sede jurisdicional, quando tal se impuser, a plenitude de meios que lhes permitam exercer, de modo efetivo, os direitos fundamentais que a todos, sem distinção, são assegurados" (grifos do original). ${ }^{54}$

A interpretação da Suprema Corte nesse caso delineia parâmetros importantes para a possibilidade de interferência do Poder Judiciário, por meio de suas decisões, no planejamento. Extrai-se do julgado que é legítimo o reconhecimento do estado de coisas inconstitucional, uma vez constatada a inércia do Poder Público que caracterize grave omissão diante da violação a direitos fundamentais, justificando a intervenção para, como expresso no voto do Ministro Marco Aurélio, "retirar os demais Poderes da inércia, catalisar os debates e novas políticas públicas, coordenar as ações e monitorar os resultados". Intervenção essa cujos limites são traçados de modo a não permitir intromissão nas esferas de atuação dos outros poderes. Deve ser equilibrada, não se substituindo aos demais Poderes, formulando ordens flexíveis, sem definir o conteúdo das ações, nem detalhar as medidas e escolhas orçamentárias, mas tão somente oferecendo incentivos, parâmetros e objetivos para a atuação própria de cada um, acompanhando e monitorando a implementação das providências que vierem a ser adotadas.

É precisamente o que se pleiteia no pedido final, que consiste na determinação para que o governo federal elabore um Plano Nacional, e os governos estaduais e distrital que os respectivos planos, de forma harmônica ao Plano Nacional, contendo os elementos necessários para a solução dos problemas que afligem o sistema penitenciário

53 BRASIL. Supremo Tribunal Federal. ADPF $347 M C$, Voto Min. Edson Fachin.

54 BRASIL. Supremo Tribunal Federal. ADPF $347 M C$, Voto Min. Celso de Mello. 
brasileiro, de modo a assegurar o cumprimento da Constituição, com a participação do Poder Judiciário na avaliação das medidas e na homologação do Plano, bem como em seu monitoramento e implementação. Em outras palavras, vê-se estar o pedido formulado nos exatos limites do que constou na fundamentação da decisão no pedido cautelar, com o Poder Judiciário exercendo o papel de guardião da Constituição e, nessa função, obrigando o Poder Público a agir no sentido de tomar as medidas que sejam necessárias para fazer cessar uma situação de grave descumprimento generalizado de dispositivos constitucionais asseguradores de direitos fundamentais. E impondo obrigações que dão ampla liberdade à Administração Pública, pelos seus Poderes e órgãos envolvidos, de o fazerem na forma que melhor lhe convirem, desde que se mostre adequada e suficiente para solucionar a questão em prazo razoável e fazer cessar o estado de coisas inconstitucional.

Já foi demonstrado anteriormente que o planejamento é instrumento fundamental para que o Estado brasileiro possa atingir seus objetivos fundamentais expressos na Constituição. No caso específico da situação carcerária, mostra-se ainda mais relevante, não só por envolver a garantia dos direitos fundamentais mais elementares para todo ser humano, como vida, saúde e liberdade, mas também por exigir uma complexa "engenharia" do setor público, uma vez que envolve aspectos federativos, setoriais e participação intensa e em cooperação de órgãos e poderes independentes. ${ }^{55}$

Em havendo direitos e garantias fundamentais assegurados na Constituição, vários dos quais dependem da atuação do Estado para se concretizarem, a sociedade tem o direito de exigi-los. Nada mais adequado, em se tratando de direitos cuja fruição dar-se-á após complexa atuação do Estado, a quem caberá implementar políticas públicas que exigem prévio planejamento, por vezes um pré-requisito indispensável, que a sociedade cobre do Estado que promova o início da implementação das referidas políticas públicas da forma correta, ou seja, precedida de adequado planejamento. É, pois, legítimo e correto demandar junto ao Poder Judiciário que imponha à administração pública agir no sentido de concretizar, mediante planejamento, a implementação das referidas políticas públicas que resultarão na concretização dos direitos fundamentais cuja fruição está garantida pela Constituição.

Nesse sentido, vale destacar os argumentos desenvolvidos por Juliano Veloso, que discorreu exaustivamente sobre o assunto em obra dedicada ao tema do planejamento. Pondera sobre os limites do ativismo judicial, reconhecendo que "os tribunais podem não ser o melhor local para solucionar os diversos problemas de implantação

Como já abordado em texto de minha autoria, "Solução para a crise carcerária tem significativo reflexo orçamentário", publicado no livro Levando o direito financeiro a sério, p. 83-88. 
de políticas públicas", até mesmo porque os tribunais "têm dificuldade de estabelecer a conduta devida pela Administração, tendo em vista tratar-se também de questões políticas e técnicas, além das de competência e jurisdição" ${ }^{56}$ Há que se considerar, entretanto, que o planejamento "ocupa papel de protagonista na efetivação dos direitos, visto que é o primeiro ato jurídico do processo administrativo da Política Pública, condição sine qua non para a efetivação de direitos fundamentais". Sendo assim, o "cidadão pode e deve exigir a elaboração e a execução do Planejamento, seja por meio judicial ou político". E defende existir assim um direito ao planejamento, que "pode ser exigido administrativamente ou judicialmente, tanto para a elaboração do Plano como para a sua execução, no prazo determinado". ${ }^{7}$

Os argumentos ora desenvolvidos justificam a interferência do Poder Judiciário não somente nas hipóteses em que se exige a implementação de normas de planejamento, como mostramos no início deste item, mas também eventual alteração, com a inclusão, exclusão ou modificação dos elementos nas quais se decompõem, como ações, objetivos e/ou metas, uma vez que os fundamentos são os mesmos.

O planejamento orçamentário é, inicial e essencialmente, atividade típica e compartilhada entre os Poderes Executivo e Legislativo, ${ }^{58} \mathrm{em}$ face do que dispõe o art. 165 da Constituição, que atribui ao Poder Executivo a iniciativa das leis de planejamento orçamentário. No entanto, sendo muitas vezes um instrumento essencial para viabilizar a concretização de direitos, não há como excluir a participação ativa do Poder Judiciário em hipóteses excepcionais, como as anteriormente descritas, e de forma limitada, para que, sem violar e interferir na esfera de competência dos demais poderes, atue no sentido de compelir o Poder Público a exercer o dever de planejar, quando este se faça imprescindível para assegurar direitos fundamentais.

\subsubsection{O Poder Judiciário e a judicialização do planejamento na fase de execução}

No segundo grupo da proposta feita no início deste item de classificação das possibilidades de judicialização do planejamento orçamentário, está-se diante da existência concreta de uma norma de planejamento, em que o acesso ao Poder Judiciário faz-se necessário para dar-lhe eficácia em face do seu não cumprimento.

VELOSO, Juliano. Direito ao planejamento, p. 170.

VELOSO, Juliano. Direito ao planejamento, p. 199-200.

58 Sob a perspectiva de Poderes do Estado, e não de órgãos da Administração Pública, pois, nesta última, ter-se-ia de analisar as prerrogativas dos órgãos que têm iniciativa de sua proposta orçamentária, que não é o caso neste momento. 
O Tribunal de Justiça de São Paulo decidiu caso ${ }^{59}$ que apresenta particularidades importantes para esta situação, sendo de interesse conhecê-lo para analisar hipóteses em que se constata a judicialização voltada a fazer cumprir normas de planejamento.

Trata-se de ação civil pública movida em face da municipalidade de São Paulo na qual se pleiteou a construção de creches para 736 crianças e ampliação do número de vagas de modo a atender a toda a demanda oficialmente cadastrada. A decisão final, no que interessa mais diretamente ao tema ora em discussão, obrigou o Município de São Paulo a criar, "entre os anos de 2014 a 2016, 150 mil novas vagas em creches e pré-escolas para crianças de zero a cinco anos de idade", incluindo "na proposta orçamentária a ampliação da rede de ensino atinente à educação infantil de acordo com a ampliação determinada" e "obrigar o Município de São Paulo a apresentar a este Juízo, no prazo máximo de 60 (sessenta) dias, plano de ampliação de vagas e de construção de unidades de educação infantil".

Releva destacar que o compromisso de atender à demanda de educação infantil está consubstanciado no Programa de Metas 2013-2016 do Município de São Paulo, ${ }^{60}$ como mencionado no acórdão, havendo, portanto, uma norma de planejamento que já materializou juridicamente o objetivo que a decisão judicial determinou à municipalidade que seja cumprido.

Sendo assim, vê-se que na demanda há tanto a exigência de cumprimento de normas de planejamento existentes - que é o que se pretende analisar e discutir quanto a imputação de obrigação ao exercício do dever de planejar, com a inclusão na proposta de lei orçamentária da ampliação da rede de ensino infantil e a apresentação de plano de ampliação de vagas - o que foi objeto de análise no item anterior.

TJSP, registro 2013.0000792670, autos de Apelação 0150735-64.2008.8.26.0002, Ação Civil Pública n. 0150735-64.2008.8.26.0002, apelantes Ação Educativa Assessoria Pesquisa e outros, apelada Municipalidade de São Paulo, Câmara Especial, j. 16.12.2013, Rel. Des. Walter de Almeida Guilherme.

60 O Programa de Metas é um instrumento jurídico de planejamento governamental próprio do Município de São Paulo, estando previsto na respectiva Lei Orgânica, art. 69-A, e deve ser apresentado pelo Prefeito eleito até 90 dias após a posse, contendo as ações estratégicas, os indicadores e as metas quantitativas para cada um dos setores da Administração Pública Municipal, das Subprefeituras e dos Distritos da cidade. O PPA 2014-2017 contemplou o Programa de Metas estabelecendo que os programas devem ser compostos por "ações e detalhamento correspondentes do Programa de Metas 2013-2016” (Lei Municipal n. 15.949/2013, art. 5, \$ 1, VI). O Programa de Metas para o período de 2013 a 2016 prevê como Objetivo 3 "Ampliar em 150 mil a oferta de vagas para a educação infantil, assegurando a universalização do atendimento em pré-escola para crianças de 4 e 5 anos, atendendo a demanda declarada por creches em 1.1.2013 e consolidando o Modelo Pedagógico Único”. 
Destacam-se na fundamentação do acórdão os argumentos que demonstram haver um dever constitucional do Estado, que configura um direito subjetivo reconhecido pelo ordenamento jurídico, de atender à demanda de educação infantil, que não pode ser obstaculizado de forma a impedir que se materialize esse direito fundamental, ligado à dignidade humana. A ingerência do Poder Judiciário, nesse caso, não viola os princípios da separação e da independência dos poderes, pois, havendo omissão do Poder Executivo em efetivar um direito garantido na Constituição, a interveniência do Poder Judiciário é legítima.

O direito pleiteado está fundado em dispositivos constitucionais e legais que não deixam margem a dúvidas quanto ao respaldo jurídico, conforme ressaltado pelo relator:

"Foi claro o Poder Constituinte Originário ao estabelecer como dever do Estado, em todas as esferas federativas, propiciar 'educação infantil, em creche e pré-escola, às crianças até 5 (cinco) anos de idade' (art. 208, inciso IV, da Constituição Federal de 1988, com redação dada pela Emenda Constitucional n. 53/2006). O mesmo comando emerge do disposto no artigo 54, incisos I e IV, do Estatuto da Criança e do Adolescente - Lei n. 8.069/90. Fixada a garantia constitucional, a Carta Magna, ao direcionar as atribuiçõoes de cada uma das pessoas políticas no tocante à organização do ensino, impôs aos Municípios atuação prioritária 'no ensino fundamental e na educação infantil' (art. 211, $\$ 2^{\circ}$, da CF/88, com redação dada pela Emenda Constitucional n. 14/96) e aos Estados e Distrito Federal, no 'ensino fundamental e médio' (art. 211, $\$$ 3o, da CF/88)".

Sendo "indiscutível, portanto, o dever constitucionalmente fixado de a Municipalidade de São Paulo fornecer educação infantil às crianças, não havendo que se falar, portanto, na impossibilidade jurídica do pedido”. Assim,

"se Constituição da República afirma ser dever constitucional do Estado assegurar à criança o direito à educação infantil, obriga-se o Poder Judiciário, no intuito inarredável de fazer cumprir a Constituição, exigir do Poder Executivo tornar efetivo o direito praticando atos concretos tendentes à sua materialização, não sendo a incumbência inibida pela alegação de que assim agindo estaria se imiscuindo na esfera específica de atuação do último Poder”.

De modo que, "se o Poder Executivo deixa, porventura, de efetivar um direito garantido na Lei Básica, a interveniência do Poder Judiciário se faz legítima e incontrastável", não constituindo a atuação do Poder Judiciário "lesão ao princípio constitucional da independência e harmonia dos poderes, ao contrário, a ele se conforma, pois, ao exigir a observância de direito consagrado na Constituição, não está ele se pronunciando sobre o mérito administrativo, relacionado às conveniências do Governo, mas sim fazendo respeitar as determinaçōes do legislador constituinte”. E destaca a Súmula 65 do Tribunal de Justiça de São Paulo, segundo a qual 
"Não violam os princípios constitucionais da separação e independência dos poderes, da isonomia, da discricionariedade administrativa e da anualidade orçamentária as decisões judiciais que determinam às pessoas jurídicas da administração direta a disponibilização de vagas em unidades".

A questão de fundo, referente à possibilidade de exigir judicialmente o cumprimento das normas de planejamento existentes - o que permite dizer estarem em fase de execução -, ainda que seja nova, tem direta relação com a impositividade das normas de planejamento, no que não diferem substancialmente da lei orçamentária.

Embora seja questão polêmica e antiga no âmbito do direito financeiro, não é o caso de se discorrer longa e minuciosamente sobre tema, a fim de não se desviar do foco do trabalho, atribuindo-se desproporcional importância em face dos demais assuntos que serão tratados. Necessário, contudo, expor os principais aspectos que permitam compreender a legitimidade e o alcance da intervenção do Poder Judiciário ora em discussão.

A questão da impositividade no âmbito da lei orçamentária, que pode, com as devidas cautelas e adaptaçôes, ser transportada para as demais leis de natureza orçamentária, é questão cuja discussão precisa ser atualizada, não se pode mantê-la nos mesmos termos em que durante muito tempo foi colocada, limitada a uma dicotomia entre a natureza "autorizativa" ou "impositiva".

A lei orçamentária hoje não está isolada, integra um conjunto de normas que compõem um sistema de planejamento orçamentário da administração pública, e sua análise contextualizada não permite mais considerar a hipótese de que, em face desse novo desenho institucional do planejamento, tenha uma natureza meramente autorizativa, tornando essa posição ultrapassada.

Querer limitar a lei orçamentária a uma norma cuja função restringe-se tão somente a dar cumprimento ao princípio da legalidade, como um instrumento que faz constar as despesas para que se possa executá-las por estarem legalmente previstas e, portanto, autorizadas, deixando a critério discricionário do gestor realizá-las ou não, sem que isso importe em qualquer obrigação, configurando mera faculdade, sem que tenha qualquer grau de impositividade, é fazer pouco da lei já reconhecida como a mais importante logo após a Constituição, como já mencionado na primeira frase que abre este trabalho.

A integração da lei orçamentária ao sistema de planejamento orçamentário da administração pública faz dela um instrumento do planejamento fundamental para atingir os objetivos do Estado, democraticamente fixados na Constituição e na legislação infraconstitucional, cabendo ao Poder Público atuar no sentido de atingi-los, o que não configura uma faculdade, mas sim um dever do gestor público, 
que o ordenamento jurídico explicita por meio das leis de planejamento orçamentário, em que estão estabelecidos os meios e objetivos a serem alcançados.

As leis de planejamento orçamentário, portanto, devem ser cumpridas, tendo evidente natureza impositiva, não havendo modernamente como sustentar tese diversa. As questôes que se colocam, em face das peculiaridades das leis de planejamento orçamentário, são o modo e o grau que se deve reconhecer às obrigações impostas pelas referidas leis, suas condições e limites, a fim de que se possa saber o exato conteúdo da impositividade das leis de planejamento orçamentário.

$\mathrm{Na}$ linha do que foi exposto, em análise voltada especificamente à lei orçamentária, já afirmamos anteriormente que

"é preciso também que se reconheça e se atribua efetivamente o caráter impositivo à lei orçamentária, abandonando a tese, que boa parte da doutrina já deixou de lado, de que o orçamento é lei meramente 'formal', 'autorizativa', sem caráter 'mandatório' ou 'impositivo', tornando facultativas suas disposiçôes. Entendimento que não se coaduna com o atual sistema de planejamento governamental, em que as leis orçamentárias representam os principais instrumentos e dependem de seu fiel cumprimento para que se concretizem as ações tal como planejadas. (...) Com efeito, não é mais possível deixar de reconhecer o caráter material da lei orçamentária, ante as inúmeras funções por ela exercidas no âmbito do planejamento, gestão e controle, cujos dispositivos contêm autorizações, proibições e determinações, e vinculam a ação do administrador a perseguir os objetivos e metas, ${ }^{61}$ (não sendo) coerente com o ordenamento jurídico vigente, que tem a lei orçamentária contextualizada em um sistema de planejamento governamental, na qual desempenha papel fundamental, considerar as disposiçōes da lei orçamentária meras 'autorizações' para as despesas públicas. Acolher tal interpretação é fazer pouco dessa lei tão relevante. Ainda que sejam necessários instrumentos de flexibilidade que permitam adequar as disposiçōes da lei orçamentária às inevitáveis intercorrências que surgem no decorrer do exercício financeiro, há que se reconhecer o caráter mandatório - ou 'impositivo' - da lei orçamentária”. ${ }^{62}$

Os estudiosos do tema não têm mais deixado dúvidas sobre essa interpretação, única compatível com as atuais funções que o sistema de planejamento orçamentário cumpre no ordenamento jurídico.

Heleno Torres deixa clara a natureza impositiva das leis de planejamento orçamentário ao tratar do tema. Expõe que o "planejamento orçamentário é o mínimo de eficácia do art. 174, que não se pode limitar ou bastar por este, de duração

61 CONTI, José Mauricio. Orçamento não pode ser mais uma peça de ficção. Levando o direito financeiro a sério, p. 189-193.

62 CONTI, José Mauricio. Aprovação do "orçamento impositivo" é insuficiente para dar credibilidade à lei orçamentária. Levando o direito financeiro a sério, p. 191-192. 
restrita no tempo, mas que permite sua conexão com a regulação da ordem econômica e com o dirigismo estatal", e, com "a ascensão do Estado Social, o orçamento foi alçado à condição de instrumento fundamental ao planejamento do Estado". ${ }^{63}$ A Lei de Responsabilidade Fiscal, ao cuidar do planejamento, é clara ao incluir as três leis de planejamento orçamentário, quais sejam, o Plano Plurianual, a Lei de Diretrizes Orçamentárias e a Lei Orçamentária Anual, qualificados pela função de planejamento, "o que se verifica de modo impositivo e vinculante". ${ }^{44} \mathrm{E}$ finaliza:

"Ora, no Estado Democrático de Direito, o planejamento não é uma opção ou algo meramente indicativo. Trata-se de comando impositivo, segundo os princípios definidos pela Carta Constitucional. É criticável a ausência de um planejamento de longo prazo, que ordene o desenvolvimento ao longo de décadas e cumpra aquelas magnas funçōes dos arts. $3^{\circ}$ e 43, para assegurar a erradicação da pobreza e a eliminação de desigualdades regionais. Contudo, a Constituição obriga ao mínimo de planejamento que foi atribuído ao plano plurianual, como instrumento de direcionamento das açōes do Estado, com vistas a realizar os fins constitucionais, mediante intervencionismo, para o qual a lei de diretrizes orçamentárias e a lei de orçamento anual devem propiciar todas as condiçōes de concretização". ${ }^{65}$

Ao mesmo resultado se chega pelo raciocínio de Juliano Veloso, ao defender a efetividade das normas de planejamento: "O Planejamento somente será institucionalizado se for capaz de produzir resultados concretos e efetivos", diz, e, muitas vezes, a concretização dos direitos não se verifica "em função da falta de orientação do ordenamento jurídico em torno do Planejamento". Nesse sentido, o "Estado deverá, antes de realizar qualquer gasto, ter objetivos apropriados, para que, então, possa se maximizar a utilização do recurso. Dever-se-á ter clareza no direcionamento dos planos para que, então, possa se mensurar a efetividade e, finalmente, atender ao ordenamento". ${ }^{66}$ Considerando que a finalidade da lei é tornar efetivos seus desideratos, e os atos e processos administrativos somente serão efetivos se cumpridos os objetivos da lei e os critérios forem respeitados, o planejamento deve abranger a avaliação do resultado esperado e do resultado alcançado, e conclui que "o princípio da finalidade coincide com o da efetividade, fundamental para a concretização dos direitos fundamentais por meio do Planejamento”. Há uma ligação de interdependência e complementaridade entre a legalidade, a eficiência, a eficácia

63 TORRES, Heleno Taveira. Direito constitucional financeiro. Teoria da constituição financeira, p. 352-353.

64 TORRES, Heleno Taveira. Direito constitucional financeiro. Teoria da constituição financeira, p. 355.

65 TORRES, Heleno Taveira. Direito constitucional financeiro. Teoria da constituição financeira, p. 356.

66 VELOSO, Juliano Ribeiro dos Santos. Direito ao planejamento, p. 146-149. 
e a efetividade dos atos e processos administrativos para que os objetivos do Estado sejam alcançados, tendo o planejamento uma importância fundamental nessa lógica, e "os riscos de se furtar a apreciação do Planejamento, da eficiência e da eficácia dos atos administrativos, no que tange à efetivação dos direitos fundamentais, é o mesmo de manter-se fora da realidade"; assim, o "controle judicial deve ocorrer também com fundamento na lei planejadora, buscando a efetividade, a produção de efeitos jurídicos focados em resultados concretos" ${ }^{67}$

Mais adiante, ao discorrer sobre o ativismo judicial em matéria de planejamento, corrobora a decisão do Ministro Celso de Mello, ${ }^{68}$ no sentido de que a inércia da Administração configura desrespeito à Constituição, devendo o Poder Judiciário tomar medidas efetivas de execução das políticas públicas, e acrescenta que o "planejamento vem justamente demonstrar o caminho da razoabilidade na execução dessas decisões", cabendo à administração "somente estabelecer cronograma de implantação, bem como os objetivos e as metas, de forma racional, como é assegurado pelo direito do planejamento". ${ }^{69}$

As normas de planejamento, dessa forma, podem ser vistas como instrumentos essenciais para permitir que o Estado atinja seus objetivos, cumprindo suas obrigações de maneira eficiente, eficaz e efetiva, e somente com a observância e o cumprimento das normas de planejamento se consegue atingir concretamente os objetivos do Estado, viabilizando a implementação e a consequente fruição dos direitos fundamentais.

Em seu estudo sobre a natureza jurídica do orçamento, Rodrigo Faria inova na análise do tema, estabelecendo com grande acuidade e precisão a interpretação que se compatibiliza com as modernas funções do orçamento no contexto de uma administração pública que caminha no sentido de buscar melhores resultados, tendo nas leis que compõem o sistema de planejamento orçamentário um instrumento fundamental para essa nova administração pública. A argumentação é útil para delinear o sentido que se deve dar às demais normas de planejamento orçamentário, como se verá.

$\mathrm{O}$ autor inicialmente deixa claro que se deve reconhecer serem as leis orçamentárias compostas de um complexo de comandos. As leis orçamentárias contêm uma pluralidade normativa, conjugando concomitantemente comandos de autorizações, proibições e determinações, e devem ser analisadas na sua integralidade para que se possa avaliar sua natureza jurídica, não sendo possível circunscrever-se

\footnotetext{
67 VELOSO, Juliano Ribeiro dos Santos. Direito ao planejamento, p. 151-157.

68 Supremo Tribunal Federal. AI 598.212 ED, Rel. Min. Celso de Mello, j. 25.3.2014.

69 VELOSO, Juliano Ribeiro dos Santos. Direito ao planejamento, p. 193-195.
} 
tão somente à dotação orçamentária, que, analisada isoladamente, pode dar uma conotação de que tenha caráter meramente autorizativo, uma vez que indicam os recursos financeiros, que são meios pelos quais se viabilizará o alcance dos objetivos pretendidos. No que tange ao aspecto de obrigatoriedade, que interessa para o que se argumentará, "o principal núcleo obrigatório das leis orçamentárias são os seus fins. Os fins orientam a estruturação das leis orçamentárias e lhes conferem direção e sentido, de modo que o administrador público fica vinculado ao alcance dos objetivos e metas fixados, devendo envidar os esforços necessários à plena desincumbência das tarefas que lhe foram cometidas", que, no caso do Plano Plurianual, "assumem a forma de objetivos estratégicos", na LDO, de metas fiscais, e na LOA de objetivos programáticos. Havendo metas a serem alcançadas, como no exemplo da LDO, "existe um nítido viés de obrigação ou esforço a ser despendido pelos órgãos arrecadadores no intuito de alcance dos objetivos anteriormente fixados". E chama a atenção para o fato de que "o descumprimento da Lei de Orçamento não se revela por aspectos formais ou de meras divergências entre previsões e execução (...), visto que tais aspectos não dão conta do alcance das finalidades pretendidas pela execução do Orçamento", devendo ser eventual descumprimento constatado pelo "número de programas que não alcançaram as finalidades a que se propunham, pelo descumprimento das metas fiscais que orientavam a lei orçamentária, pelos resultados ineficientes e ineficazes alcançados". Tendo em vista ser claro que os objetivos e metas da lei de orçamento são obrigatórios, vinculando a Administração Pública ao seu alcance, há que se reconhecer a natureza material da lei orçamentária e seu caráter impositivo. ${ }^{70}$

A fixação de objetivos e metas a serem obrigatoriamente perseguidos pela Administração Pública é própria de todas as leis que integram o sistema de planejamento orçamentário. Por essa razão, é preciso reconhecer nelas a natureza de leis materiais com caráter impositivo, não havendo que se falar em diplomas legais meramente formais no âmbito das normas de planejamento orçamentário.

As mesmas conclusões podem ser extraídas a partir das lições de Eros Grau, que identifica com precisão as chamadas "normas-objetivo", categoria cujas características se veem presentes nas normas de planejamento orçamentário, permitindo nelas reconhecer plena eficácia.

A norma-objetivo, em síntese, conforme expõe o autor, não define conduta nem organização. São normas que determinam fins a serem alcançados, fixando

70 FARIA, Rodrigo Oliveira. Natureza jurídica do orçamento e flexibilidade orçamentária, especialmente Capítulo 4 e conclusões (grifos do original). 
objetivos, nas quais o legislador enuncia "resultados concretos a cujo alcance deve voltar-se a atividade dos seus destinatários", incluindo como exemplos de normas-objetivos infraconstitucionais os planos nacionais e setoriais. ${ }^{71}$ Por meio das referidas normas, o Estado se compromete a "alcançar um certo resultado de caráter econômico e a tal escopo predispõe os meios - ou melhor, estabelece anteriormente aqueles que os consociados devem empregar" ${ }^{72}$ Com o reconhecimento da categoria das normas-objetivo, o Direito passa a ser também um instrumento de governo, de forma a atuar tendo em vista "a implementação de políticas, políticas estas referidas a fins múltiplos e específicos”, e as normas-objetivo surgem voltadas "para a definição jurídica desses múltiplos e específicos fins”. As normas-objetivo definem obrigaçôes de resultado e não de meios, ficando "a opção pelos meios a serem adotados para o alcance dos resultados (...) para os destinatários das referidas normas". ${ }^{73}$ E sua plena eficácia jurídica se evidencia pelos fins nelas definidos, que produzem efeitos jurídicos ao regular situações, relações e comportamentos de modo a condicionar "o dinamismo de aplicação das normas de conduta e de organização das parcelas do ordenamento a que estejam referidas". ${ }^{4}$

Embora os exemplos citados pelo mestre direcionem-se às normas de planejamento econômico, as características neles presentes ajustam-se com perfeição às normas de planejamento orçamentário, que têm em sua essência a fixação de objetivos serem cumpridos, que criam para a administração pública o dever de persegui-los, como ficou também claro na argumentação anteriormente exposta baseada na tese desenvolvida por Rodrigo Faria, já mencionada.

De todo o exposto, pode-se concluir com segurança serem as normas de planejamento orçamentário dotadas de plena eficácia, sendo legítimo o controle judicial, cabendo ao Poder Judiciário, uma vez chamado a intervir, agir para assegurar o cumprimento das determinações nelas contidas.

71 E ainda, "na disposição da lei do plano que aprova as diretrizes e prioridades nele contidas: define os fins da política econômica a ser empreendida pelo Estado dentro de um determinado período de tempo" (GRAU, Eros Roberto. Notas sobre a noção de norma-objetivo. Revista de Direito Público, p. 145).

72 GRAU, Eros Roberto. Notas sobre a noção de norma-objetivo, p. 137-138 (grifos do original).

73 GRAU, Eros Roberto. Notas sobre a noção de norma-objetivo, p. 140-141 (grifos do original).

74 GRAU, Eros Roberto. Notas sobre a noção de norma-objetivo, p. 147. 